\title{
Review \\ A Potential Interface between the Kynurenine Pathway and Autonomic Imbalance in Schizophrenia
}

\author{
Alexandra Büki ${ }^{1}$, Gabriella Kekesi ${ }^{1} \mathbb{1}$, Gyongyi Horvath ${ }^{1} \mathbb{D}$ and László Vécsei ${ }^{2,3,4, *}$ \\ 1 Department of Physiology, Albert Szent-Györgyi Medical School, University of Szeged, Dóm tér 10., \\ H-6720 Szeged, Hungary; buki.alexandra@med.u-szeged.hu (A.B.); kekesi.gabriella@med.u-szeged.hu (G.K.); \\ horvath.gyongyi@med.u-szeged.hu (G.H.) \\ 2 Department of Neurology, Albert Szent-Györgyi Medical School, University of Szeged, Semmelweis u. 6., \\ H-6725 Szeged, Hungary \\ 3 MTA-SZTE Neuroscience Research Group, H-6725 Szeged, Hungary \\ 4 Interdisciplinary Excellence Center, Department of Neurology, Albert Szent-Györgyi Medical School, \\ University of Szeged, Semmelweis u. 6., H-6725 Szeged, Hungary \\ * Correspondence: vecsei.laszlo@med.u-szeged.hu; Tel.: +36-62-545-356
}

Citation: Büki, A.; Kekesi, G.;

Horvath, G.; Vécsei, L. A Potential Interface between the Kynurenine Pathway and Autonomic Imbalance in Schizophrenia. Int. J. Mol. Sci. 2021, 22, 10016. https://doi.org/ $10.3390 /$ ijms221810016

Academic Editor: Juan F.

Lopez-Gimenez

Received: 31 August 2021

Accepted: 9 September 2021

Published: 16 September 2021

Publisher's Note: MDPI stays neutral with regard to jurisdictional claims in published maps and institutional affiliations.

Copyright: (C) 2021 by the authors. Licensee MDPI, Basel, Switzerland. This article is an open access article distributed under the terms and conditions of the Creative Commons Attribution (CC BY) license (https:// creativecommons.org/licenses/by/ $4.0 /)$.

\begin{abstract}
Schizophrenia is a neuropsychiatric disorder characterized by various symptoms including autonomic imbalance. These disturbances involve almost all autonomic functions and might contribute to poor medication compliance, worsened quality of life and increased mortality. Therefore, it has a great importance to find a potential therapeutic solution to improve the autonomic disturbances. The altered level of kynurenines (e.g., kynurenic acid), as tryptophan metabolites, is almost the most consistently found biochemical abnormality in schizophrenia. Kynurenic acid influences different types of receptors, most of them involved in the pathophysiology of schizophrenia. Only few data suggest that kynurenines might have effects on multiple autonomic functions. Publications so far have discussed the implication of kynurenines and the alteration of the autonomic nervous system in schizophrenia independently from each other. Thus, the coupling between them has not yet been addressed in schizophrenia, although their direct common points, potential interfaces indicate the consideration of their interaction. The present review gathers autonomic disturbances, the impaired kynurenine pathway in schizophrenia, and the effects of kynurenine pathway on autonomic functions. In the last part of the review, the potential interaction between the two systems in schizophrenia, and the possible therapeutic options are discussed.
\end{abstract}

Keywords: autonomic nervous system; kynurenic acid; kynurenine pathway; schizophrenia

\section{Introduction}

Schizophrenia is a neuropsychiatric disorder, affecting about $1 \%$ of the population, frequently associated with substantial social and economic implications [1]. This generates significant healthcare costs, as central nervous system (CNS) disorders are among the most costly medical conditions (EUR 386 billion annually in the EU) [2]. Schizophrenia is characterized by positive and negative symptoms and cognitive impairments that can influence the patients' thoughts, perceptions, speech, emotions and behaviors. Positive symptoms include hallucinations, voices that converse with or about the patient and delusions that are often paranoid. Negative symptoms include flattened affect, loss of a sense of pleasure, loss of will or drive and social withdrawal [3]. Additionally, impaired cognitive function is also enduring and core feature with different manifestations [4-6].

Besides the behavioral alterations, schizophrenia is commonly associated with autonomic imbalance, that may be related to increased morbidity and mortality [7-16]. Thus, the autonomic dysfunction is associated with multiple aspects of schizophrenia pathophysiology, including symptom severity, cognitive impairment and the development of cardiometabolic comorbidities, such as metabolic syndrome and high body mass index $[8,10,11,14]$. The high number of articles (481 in August 2021) found in MEDLINE 
search using "schizophrenia and autonomic nervous system" (ANS) keywords also suggests that the disturbance of the ANS has a high impact and its treatment is very important in this patient group.

Several neurotransmitter systems are implicated in the neurobiology of schizophrenia, including dopaminergic, glutamatergic, GABAergic (gamma-aminobutyric acid, GABA), adrenergic, cholinergic and serotoninergic [17-21]. Besides the classical neurotransmitters, the kynurenine pathway (KP) metabolites (especially the kynurenic acid [KYNA]) has gained attention in the pathophysiology of schizophrenia. Elevated brain KYNA level, a neuroactive metabolite, is one of the most consistently found biochemical marker in schizophrenia [22,23]. Thus, searching in MEDLINE with "schizophrenia and kynurenic acid" keywords resulted in 270 articles (in August of 2021). KYNA acts as an antagonist of $\mathrm{N}$-methyl-D-aspartate and $\alpha-7$ nicotinic acetylcholine receptors (NMDAR, $\alpha 7 \mathrm{nAChR}$ ), both of them involved in the schizophrenia pathogenesis [24-26]. Nevertheless, at high concentrations, KYNA can also play a neuroprotective role in conditions of excitotoxicity [27-29].

Publications so far have discussed the implication of kynurenines (KYNs) and the alteration of the ANS in schizophrenia independently from each other, only few data suggest that the KP metabolites have effects on autonomic functions [30-32]. Nevertheless, the coupling between them in schizophrenia has not yet been addressed, even though their direct common points, potential interaction or similar therapeutic application targets indicate the consideration of their interaction.

The primary aim of this review is to discuss the potential interface between these systems. In Section 2, the alterations of ANS in schizophrenia are characterized (Figure 1). In Section 3, the impaired KP is reviewed in schizophrenia. In Section 4, the effects of KP on autonomic functions are discussed. The Section 5 considers the effects of antipsychotic drugs on these systems, the potential interaction of the ANS and KP in schizophrenia and gathers some novel molecules and therapeutic options along with their targets, which may affect the KP and autonomic functions in schizophrenic patients. Since earlier reviews have discussed the clinical significance of this pathway with regards to psychiatric disorders, this study focuses shortly on this topic in the last part of the review $[29,33,34]$.

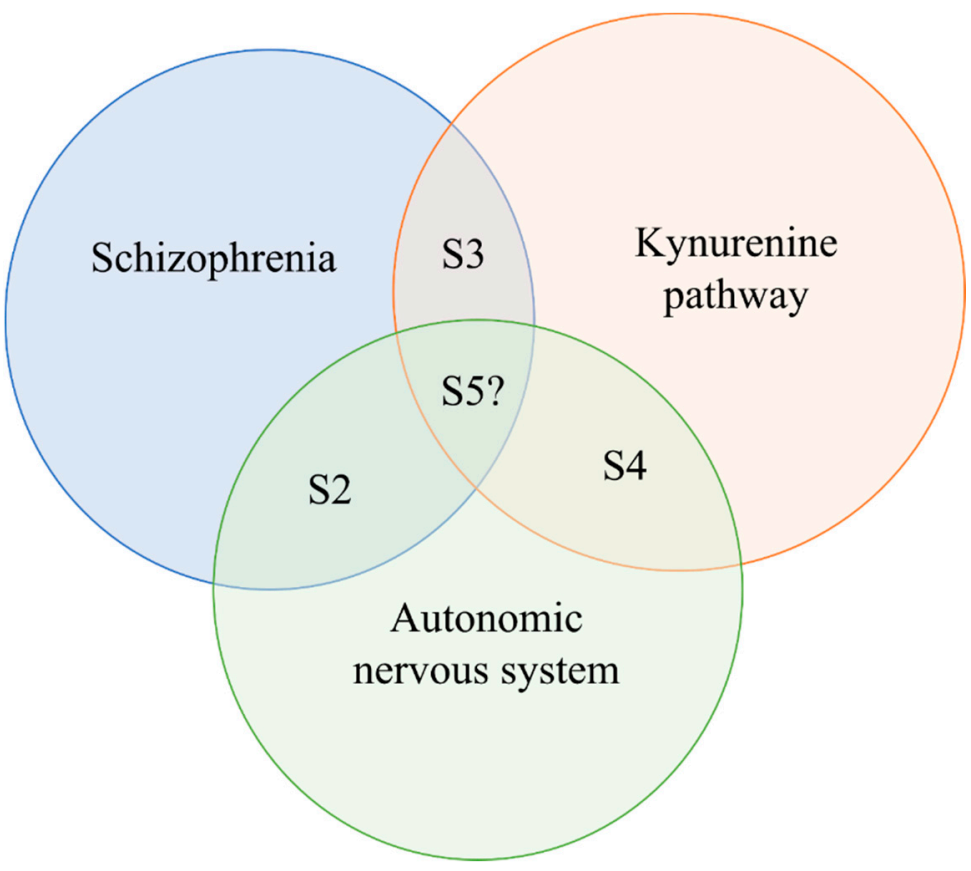

Figure 1. The paradigm of the review. Abbreviation: S: section.

\section{Autonomic Regulation in Schizophrenia}

In 1899, Emil Kraepelin described extensive autonomic alterations in patients with schizophrenia, such as increased heart rate, altered pupillary function, increased sweating 
and salivation, as well as abnormal thermoregulation (Table 1) [9,35]. Since Kraepelin's publication, several studies suggested impaired ANS activity of these patients compared to the general population [15,36-38]. The majority of the research has clearly implicated that the ANS imbalance is more likely a result of diminished parasympathetic rather than elevated sympathetic activity, so the poor parasympathetic modulation is accompanied by relative sympathetic nervous system dominance $[8,11,39,40]$. However, few studies have reported conflicting findings in relation to the evidence presented above. While some authors did not find evidence of sympathovagal imbalance, others found an augmented sympathetic activity in schizophrenic patients [10,41-44], or alterations both in sympathetic and parasympathetic activities $[10,45]$.

Table 1. Autonomic nervous system related clinical and preclinical findings in schizophrenia.

\begin{tabular}{|c|c|c|c|c|}
\hline ANS Assessment & Clinical Findings & References & Preclinical Findings & References \\
\hline Blood pressure & $\begin{array}{l}\text { Moderately higher systolic and } \\
\text { diastolic blood pressure }\end{array}$ & [39] & & \\
\hline $\begin{array}{l}\text { Blood pressure } \\
\text { variability }\end{array}$ & No changes & [39] & & \\
\hline Heart rate variability & Reduced complexity & {$[7,46,47]$} & & \\
\hline \multirow{3}{*}{ Thermoregulation } & $\begin{array}{l}\text { Abnormal diurnal variation of } \\
\text { body temperature }\end{array}$ & {$[48]$} & $\begin{array}{c}\text { PCP rat model: } \\
\text { Acute PCP: hypothermia } \\
\text { Chronic PCP: hyperthermia } \\
\text { Perinatal PCP: long-lasting effect } \\
\text { on the baseline temperature }\end{array}$ & {$[49,50]$} \\
\hline & $\begin{array}{l}\text { Impaired ability to heat stress } \\
\text { adaptation } \\
\text { Higher skin conductance } \\
\text { Disturbed sympathetic skin } \\
\text { responses }\end{array}$ & {$[44,48,51-60]$} & \multirow[t]{2}{*}{$\begin{array}{l}\text { Wisket rat model: } \\
\text { Higher body temperature, } \\
\text { Higher alteration rate }\end{array}$} & \multirow[t]{2}{*}{ [61] } \\
\hline & Higher rate of sweating & {$[62]$} & & \\
\hline \multirow{3}{*}{ Pupil function } & $\begin{array}{l}\text { Increased resting pupil } \\
\text { diameter }\end{array}$ & {$[8]$} & \multirow{3}{*}{$\begin{array}{c}\text { Wisket rat model: } \\
\text { Sedation-several parameters } \\
\text { disturbed } \\
\text { Anesthesia-prolonged } \\
\text { constriction and redilation } \\
\text { processes, blunted differences }\end{array}$} & \multirow{3}{*}{ [63] } \\
\hline & $\begin{array}{l}\text { A "sluggish" parasympathetic } \\
\text { function by light }\end{array}$ & {$[64]$} & & \\
\hline & $\begin{array}{c}\text { Decreased stimulus } \\
\text { sensitivity }\end{array}$ & [12] & & \\
\hline \multirow{3}{*}{$\begin{array}{l}\text { Gastrointestinal } \\
\text { system }\end{array}$} & $\begin{array}{l}\text { Increased tachygastria, } \\
\text { arrhythmia }\end{array}$ & {$[62]$} & & \\
\hline & $\begin{array}{c}\text { Delayed gastric emptying, } \\
\text { diabetic gastroparesis }\end{array}$ & {$[62,65]$} & & \\
\hline & $\begin{array}{l}\text { Correlation between salivary } \\
\alpha \text {-amylase level and psychiatric } \\
\text { symptoms }\end{array}$ & [66] & & \\
\hline Urinary system & $\begin{array}{c}\text { Enhanced urinary frequency, } \\
\text { urgency, incontinence and } \\
\text { detrusor hyperreflexia }\end{array}$ & {$[67]$} & $\begin{array}{l}\text { Wisket rat model: decreased } \\
\text { bladder volume }\end{array}$ & [68] \\
\hline
\end{tabular}

Abbreviations: ANS: autonomic nervous system, PCP: phencyclidine.

The altered ANS functions in patients with schizophrenia might be associated with the diverse physical, mental and/or behavioral symptoms. Furthermore, it contributes to poor medication compliance, worsened quality of life, increased severity of psychotic symptoms and increased mortality (including various causes of death in schizophrenia). The increased risk of premature death in patients with schizophrenia is at two to three times 
that of the general population, that has a great importance to find a potential therapeutic solutions to improve the autonomic disturbances [14,42,45,69-75].

\subsection{Symptoms Related to Autonomic Abnormalities in Schizophrenia}

The evaluation of blood pressure and heart rate variability can be used to describe autonomic regulation of the cardiovascular system. Regarding the blood pressure, even though systolic and diastolic blood pressure values were moderately higher in schizophrenic patients, its variability did not differ from controls (Table 1) [39]. The complexity of heart rate variability is indicative of cardiac adaptability, thus, the reduced complexity suggests difficulty in heart rate adaptation in response to environmental stimuli (Table 1) [7,46,47]. In antipsychotic treated patients cardiac autonomic dysregulation and reduced complexity of heart rate modulation have been reported, that highly correlated with the pharmacodynamics of the drug applied [7,46,76-78]. Thus, the strongest association of low heart rate variability was noted among schizophrenic patients on antipsychotic treatment with highaffinity muscarinic antagonism (i.e., clozapine, olanzapine and quetiapine), that further signify the autonomic dysregulation [14,79-81].

Respiration has a significant effect on heart rate oscillations, too, resulting increased parasympathetic activity. Thus, deep breathing could be considered as the most reliable test of parasympathetic function by using the respiratory peak as a quantitative measure of vagal control [82-85]. Deep breathing results increased variance and high frequency of heart rate in healthy controls, but significantly reduced response was reported in both patients with schizophrenia and their relatives, indicating diminished autonomic reactivity of cardiac functions (Table 1) [38,85].

The dysregulation of body temperature might be intrinsic to the syndrome of schizophrenia, manifested in altered baseline values, abnormal diurnal variation, and an impaired adaptation to heat and cold stress [48]. The higher skin conductance and the disturbed sympathetic skin responses to innocuous stimuli, reported in schizophrenic patients, also refers to the enhanced sympathetic nervous system activity, which showed correlation with symptom severity and poor functional outcome (Table 1) [44,48,51-60]. Significantly higher rate of sweating was also reported in schizophrenia patients (Table 1) [62].

Regarding the preclinical studies, Pechnick and George evaluated the thermoregulatory effects of phencyclidine ( $\mathrm{PCP}$, a noncompetitive NMDAR antagonist, applied as a schizophrenia model) in adult Wistar rats [49]. While acute administration of PCP produced hypothermia, chronic treatment resulted in prolonged hyperthermia [49,50] (Table 1). In a chronic, complex rat model of schizophrenia (developed by postweaning isolation rearing, subchronic ketamine treatment and selective breeding; named Wisket) higher body temperature during the active phase was accompanied by wider range of its fluctuation compared to control Wistar rats (Table 1) [61].

Pupillography is a non-invasive and cost-effective method to determine autonomic activity, and it is suitable to examine both the sympathetic and parasympathetic functions in the context of schizophrenia, too $[8,14,64]$. The main sympathetically influenced parameter is the resting pupil diameter, which is significantly increased in patients suffering from schizophrenia [8]. Furthermore, "sluggish" parasympathetic function of the pupil by light stimuli and in darkness after pharmacological manipulation was identified among schizophrenia patients [64]. For instance, to induce a pupillary light response in patients with schizophrenia, a 10-fold increase stimulus intensity was required as compared to controls [12]. Similar changes were found in Wisket rats, in which the pupillary light reflex was studied in two series after sedation (diazepam) or anesthesia (chloral hydrate) [63]. Thus, the initial and minimum pupil diameters were greater, the degree of the constriction was lower, and the flatness of the curve and the total duration of constriction were shorter in the sedated Wisket rats compared to control animals. Chloral hydrate anesthesia prolonged the constriction and redilation processes compared to the sedated animals and blunted the differences between the groups (Table 1) [63]. 
In schizophrenia patients increased sympathetic modulation within the enteric nervous system was also indicated by significantly increased amount of tachygastria and arrhythmia within the gastric pacemaker activity before and after test meal digestion [62] Additionally, gastric motility disorders, e.g., delayed gastric emptying or diabetic gastroparesis, have been observed in patients, indicating increased sympathetic modulation $[62,65]$.There is a pilot study, in which a significant correlation has been found between salivary $\alpha$-amylase level and psychiatric symptoms in schizophrenic patients (Table 1) [66]. Thus, the salivary $\alpha$-amylase reactivity could serve as a potential marker to measure the sympathetic-adrenal-medullary activity [86-88].

The vagus nerve is the chief mediator of the bidirectional communication along the gut-brain axis through cholinergic activation of nicotinic receptors on myenteric neurons $[14,89]$. Furthermore, ANS regulates the mucosal immune response and can also induce changes in gut microbiome composition and activity $[14,89,90]$. In turn, sensory afferent neurons of the vagus nerve detect a diverse range of stimuli within the intestines and gut microbiome projecting to the nucleus tractus solitarii (NTS) in the brainstem to initiate autonomic, endocrine and behavioral responses [91]. Thus, it is plausible that dysbiosis in schizophrenia may cause aberrant vagal signaling leading to e.g., cardiometabolic disturbances. Further research is needed to investigate the relationship between autonomic dysfunction and dysbiosis in schizophrenia [14].

Beside enhanced urinary frequency or urgency, incontinence and detrusor hyperreflexia were also reported as common autonomic symptoms in schizophrenic patients [67]. In a rat model of schizophrenia treated with ketamine and housed individually the bladder volume significantly decreased, suggesting also detrusor hyperreflexia (Table 1) [68].

\subsection{Action Mechanisms of ANS Dysregulation}

The precise mechanism of ANS dysregulation in schizophrenia remains unclear, both structural and functional changes might be involved. Largely divergent brain centers, including the different nuclei of hypothalamus and brainstem (e.g., locus coeruleus, LC), are associated with sympathetic and parasympathetic activity $[13,92]$. The underlying causes are likely to be a combination of "peripheral" and "central" mechanisms either with equal importance or with one playing a predominate role [48].

Although the hypothalamus comprises only $2 \%$ of the total brain volume, it is a key integrating center of endocrine, autonomic and behavioral responses and homeostatic balance [93]. The hypothalamus is connected with nearly all other brain area, e.g., various limbic structures, brainstem nuclei, thalamus, the cerebral cortex and the pituitary gland [94]. One of the most important hypothalamic nuclei of the central autonomic network is the paraventricular nucleus (PVN). Other hypothalamic nuclei in this network include the dorsomedial nucleus, the lateral hypothalamic area, the posterior hypothalamic nucleus and the mammillary nucleus [95]. So far only few studies have investigated its structural alterations in schizophrenia with inconsistent findings [96-102]. Some of them reported larger volume of hypothalamus, paraventricular nucleus and the mammillary bodies in schizophrenic patients compared to healthy controls [96-99]. However, postmortem investigations found decreased or unchanged volumes of these hypothalamic subregions [100-102].

LC neurons produce most of the norepinephrine (NE) released in the brain acting on adrenergic receptors $[19,103]$. LC projects vastly to most of the brain, including subcortical areas, such as the olfactory bulb and dorsal hippocampus; cortical areas, in particular the prefrontal cortex, and reciprocally to other neuromodulator systems, such as the cholinergic, dopaminergic and serotoninergic systems [19]. In turn, LC receives direct input from the cortex and several subcortical areas including amygdala and hypothalamus, and from giganto- and paragiganto-cellular nuclei [104]. The importance of LC in controlling autonomic function results from both direct projections to the spinal cord and projections to autonomic nuclei in the brainstem. A correlation between LC neuronal and sympathetic activities, as evidenced by parameters such as heart rate, blood pressure and cervical 
sympathetic tone, has been reported [105]. Thus, LC activation produces an increase in sympathetic activity and a decrease in parasympathetic activity via its projections. Therefore, alterations in LC activity affect the complex patterns of neuronal activity throughout the brain, observed as changes in measures of arousal and autonomic function [106].

Evidence for noradrenergic dysfunctions in schizophrenia have been proposed for decades, indicated by elevated NE level in the CSF, brain and serum of patients $[107,108]$. Abnormalities in LC itself have also been reported in schizophrenia patients with inconsistent results $[109,110]$. While in paranoid schizophrenia significantly elevated dopaminebeta-hydroxylase activity (that catalyzes the conversion of dopamine to NE) was observed in LC; in elderly schizophrenic patients its marked decrease was reported compared with age-matched controls $[109,110]$. These neurobiological impairments in schizophrenia correlate with symptoms; thus, the positive and negative symptoms are consistent with the hyper- or hypoactivity of NE system, respectively.

It has to be claimed that numerous genetic, epidemiological and clinical evidence have suggested that inflammatory pathways are also disrupted in schizophrenia, and individuals with infection, inflammation or autoimmune diseases are more susceptible to schizophrenia [111-114]. Therefore, it cannot be excluded that at least a part of the observed anatomical and physiological alterations might be due to the inflammatory disturbances.

\section{Kynurenine Pathway in Schizophrenia}

Current evidence shows that the tryptophan (TRP) metabolism, including KP is involved in the regulation of many biological systems that are dysfunctional in psychiatric disorders, such as CNS neurotransmission, immune-inflammatory, endocrine and metabolic systems [32,115]. It is highly desirable to expound on the mechanisms through which the KYNs link with many systems and ultimately influence domains such as emotion, cognition and pain [116]. The KP metabolites may underlie different psychotic and cognitive symptoms via neuromodulation [117], thus, the dysregulation of TRP metabolism has been implicated in the pathophysiology of schizophrenia [118-120]. Since KYNA, as one of the most important metabolite of KP, acts upon multiple receptors, its abnormal level may disrupt the balance of neurotransmitter systems, as has been detected in various neurodegenerative and neuropsychiatric disorders [121]. This raises the possibility that KYN metabolites have diagnostic (biomarker) and predictive value for the treatment outcome; furthermore, targeting the KP may emerge as a unique opportunity in the development of novel treatments for neuropsychiatric disorders [32,122,123].

The KP accounts for approximately $95 \%$ of TRP metabolism and involves several neuroactive metabolites. In the first, rate-limiting step of the KP TRP is oxidized by the following enzymes: indoleamine 2,3-dioxygenase 1 (IDO1), indoleamine 2,3-dioxygenase 2 (IDO2) or tryptophan 2,3-dioxygenase (TDO) (Figure 2). In most tissues, the TRP metabolism is catalyzed by IDO1,2 into $N$-formylkynurenine, then into KYN by formamidase enzyme [124]. IDOs are widely expressed in macrophages, neurons and astrocytes in the brain, and a polymorphism in the allele of IDO rs9657182 has been associated with schizophrenia [125-130]. A disbalance in the activation of IDO may be resulted in increased production of KYNA in schizophrenia leading to glutamatergic imbalance [131]. Additionally, proinflammatory cytokines, such as interferon- $\gamma$, interleukin 1 , and tumor necrosis factor $\alpha$, which might be enhanced in schizophrenia, are able to shift TRP metabolism to KYN by increasing IDO enzyme activity [114,132-135].

TDO acting in the brain and liver modulates the available quantity of TRP throughout the body [126]. The enzyme also modulates serotonin levels by reducing the amount of TRP available for synthesis of the neurotransmitter $[126,136]$. TDO is selectively upregulated in the postmortem frontal cortex of schizophrenic patients [137]. 


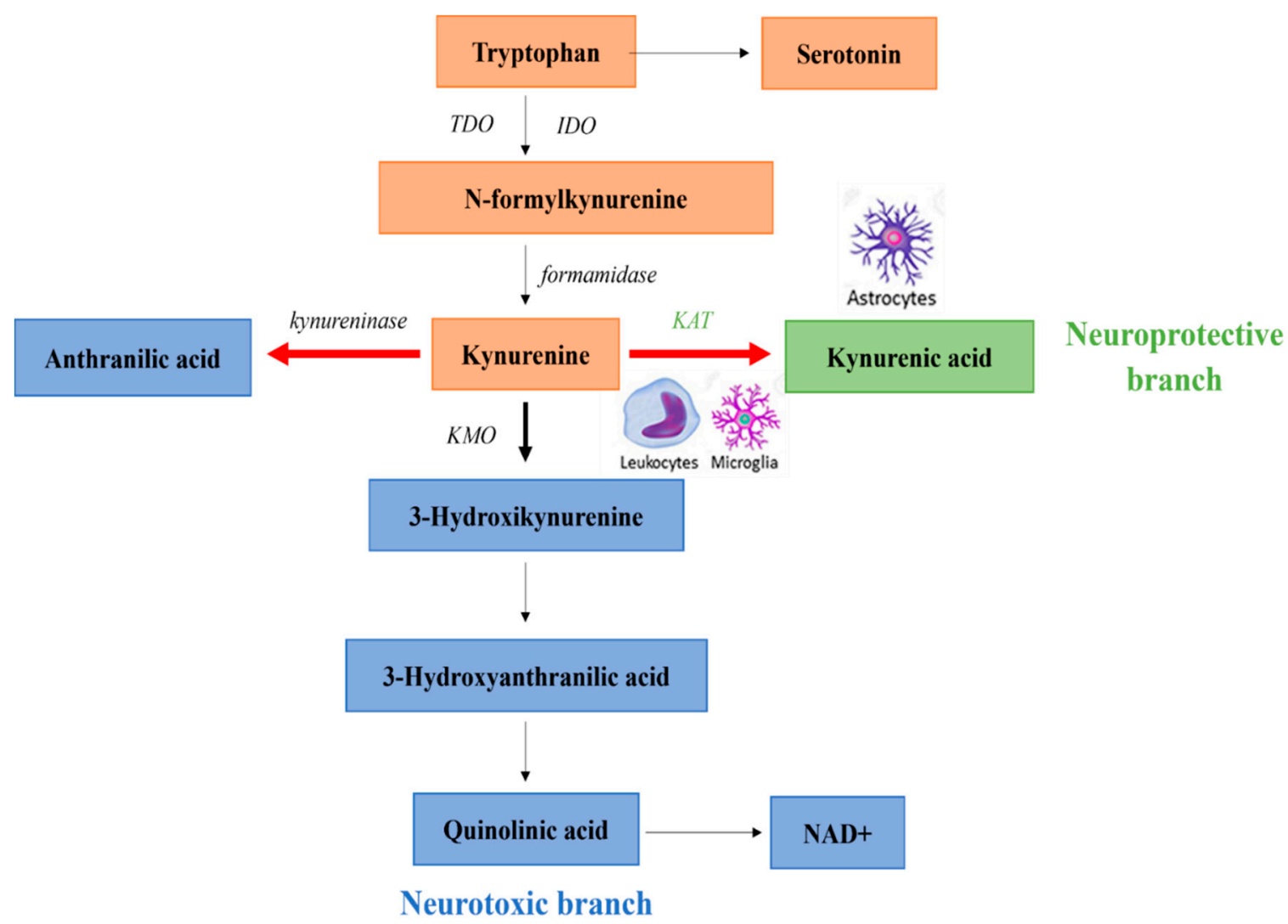

Figure 2. Kynurenine pathway (KP) in normal and schizophrenic subjects. The thick black arrow indicates the primary normal direction of KP. The thick red lines denote shifting in the direction of KP in schizophrenia. Abbreviations: IDO: indoleamine 2,3-dioxygenase, KAT: kynurenine aminotransferase, KMO: kynurenine 3-monooxygenase, NAD+: nicotinamide adenine dinucleotide, TDO: tryptophan 2,3-dioxygenase.

Diverting from the common precursor, $\mathrm{KYN}$, there are two main branches of the KP. In a neuroprotective branch, directly from KYN through irreversible transamination by kynurenine aminotransferases (KATs), KYNA is synthesized in astrocytes and neurons as a terminal metabolite $[29,138]$. Four subtypes of KATs (KAT1 to KAT4) have been identified, of which KAT1 and KAT2 are thought to have predominant roles in humans $[29,139]$ with the most abundant activities of KAT2 among them (60\%). In the other, so called neurotoxic branch of the pathway, guarded by the enzyme kynurenine 3-monooxygenase (KMO), 3-hydroxykynurenine (3-HK) is produced from KYN [114,140]. KMO is expressed either peripherally (kidney and liver) or in the brain [141]. Within the CNS, KMO is primarily expressed in the microglia cells, linking the enhanced production of KMO to inflammatory pathways [138,141,142] 3-HK is further metabolized to 3-hydroxyanthranilic acid by kynureninase that is ultimately leads to the formation of the intermediate quinolinic acid (QUIN). Subsequently, it is transformed to nicotinamide adenine dinucleotide (NAD+), which participates in basic cellular processes [29].

The role of KP disruption in schizophrenia has already been established [119,120,143]. The KYN hypothesis of schizophrenia is built upon the fact that the excess amount of KYNA can induce abnormal behavior by interfering with glutamatergic and cholinergic transmissions, and indirectly affecting dopaminergic signaling, thereby leading to schizophrenic symptoms $[25,123,144-147]$. KYNA can influence different types of receptors, possesses broad-spectrum competitive antagonist of all three ionotropic glutamate receptors. It has a stronger affinity for NMDARs, but weaker antagonistic effect on kainate and $\alpha$-amino-3hydroxy-5-methyl-4-isoxazole propionic acid receptors (KAR, AMPAR) (Table 2). In studies using human postmortem brain samples, altered expression of NMDARs, AMPARs and KARs have been found in schizophrenic patients, suggesting that the abnormal glutamate 
neurotransmission is associated with the pathophysiology of the disorder [148-150]. Data suggest that KYNA is also an $\alpha 7 \mathrm{nAChR}$ antagonist [144,151-153] (Table 2), however, a recent review claims that KYNA does not directly affect nicotinic receptors $[154,155]$.

Table 2. Receptor-binding profile of KYNA.

\begin{tabular}{lll}
\hline Receptor & Activity & References \\
\hline $\boldsymbol{\alpha} 7 \mathbf{n A C h R s}$ & antagonist & {$[154-157]$} \\
AHR & agonist & {$[158]$} \\
AMPAR & antagonist & {$[148-150]$} \\
GPR35 & agonist & {$[30,32,159,160]$} \\
KAR & antagonist & {$[149,150]$} \\
NMDAR & antagonist & {$[121,149,150,157,161-172]$} \\
\hline
\end{tabular}

KYNA has an agonistic effect on aryl hydrocarbon receptor (AHR), a transcription factor involved in the metabolism of xenobiotics [30,114,173-175], in the regulation of several physiological processes, including intestinal homeostasis, development, behavior and immunological responses $[176,177]$. A postmortem human proteomic study identified disrupted AHR signaling in hippocampus of schizophrenic patients [158]. At last, KYNA has been shown to possess agonist activity at an orphan G-protein-coupled receptor (GPR35), which predominantly detected in immune cells and the gastrointestinal tract $[30,32,164,165]$, but no data is available about a link between the GPR35 function and the pathophysiology of schizophrenia.

The reports about the affected KP have confirmed elevated KYNA level in schizophrenia, that seems to be one of the most consistently found biochemical aberrations in this disease [23,178-181]. Indeed, the higher level of brain KYNA concentration is in connection with the higher degree of cognitive impairment in schizophrenia [24,182]. Additional insight can be derived from the findings of recently published meta analyses, which determined the central and peripheral KP metabolites in schizophrenia $[183,184]$. The KYN is also elevated in both CSF and cortical brain regions, but the neurotoxic branch of the KP seems to be unaffected, since QUIN and 3-HK were found at normal levels in the postmortem schizophrenic brain $[119,178,180,181,185]$. Studies investigating peripheral serum levels of KYN, 3-HK, KYNA and QUIN detected no difference between first-episode neuroleptic-naive patients and controls $[183,186,187]$. Whereas another study suggested that enhanced serum level of $3-\mathrm{HK}$ could predict the symptom severity in schizophrenia [188]. In addition, another metabolite of the KP, anthranilic acid, is also markedly increased in serum of schizophrenia patients [189].

Further elements related to KP, including enzymes, are also altered in schizophrenia. The genetic variants of these enzymes, leading to the abnormal level of KYNA, have been linked to psychotic symptoms and cognitive dysfunctions [190-192]. In postmortem brain samples of schizophrenic patients reduced KMO activity has been reported [192]. The increased KYNA production and level may be directly related to increased KAT activity (Figure 2). In support of this finding, enhanced number of astrocytes, as the primary source of KYNA, has been found in patients with schizophrenia [186,193]. However, in a postmortem tissue analysis of schizophrenic patients revealed an increase in KYNA that was associated with decreased KMO activity rather than alterations in KAT activity $[181,194]$. The TDO activity is also upregulated in the postmortem brains of schizophrenic patients $[137,192]$.

Animal models also support the KYN hypothesis of schizophrenia [163,169,171,195]. Thus, similarly to the NMDA receptor antagonists, experimentally increased brain concentration of KYNA induces impairments in cognitive flexibility, memory, long-term potentiation and sensory gating, as well as increased amphetamine-induced locomotor activity and disturbed social interaction and reward circuitry were detected [157,161-164,167-172]. These effects might be due to the down-regulation of the permissive action of $\alpha 7 \mathrm{nAChRs,}$ since the antagonism of $\alpha 7 \mathrm{nAChR}$ by KYNA may induce psychotic symptoms [156,157]. 
In the last decade, a growing number of evidence proved the role of the interaction between inflammation and KP in the pathophysiology of schizophrenia [117]. The inflammatory mediators can unbalance the KP in schizophrenia and the resulted KP metabolites can, in turn, underlie different psychotic symptoms via modulation of neurotransmission [196].

The conventional view is that peripheral KYNA and QUIN poorly cross the bloodbrain barrier (BBB), thus, these metabolites may be derived in situ from KYN in the brain. Therefore, it was suggested that they may not necessarily play important role in the pathogenesis of schizophrenia [196]. In contrast TRP, KYN, and 3HK can be transported across the BBB $[32,197]$. Under physiological conditions $60-80 \%$ of $\mathrm{KYN}$ in the brain is exogenous origin, being actively transported across the BBB by the large neutral amino acid transporter 1 [32]. The neuroinflammation in neuropathology of schizophrenia is closely associated with the disruption of the BBB integrity due to microglial activation and elevated cytokine production, such that the entry of circulating KP metabolites into the CNS can be elevated [198-202]. Following systemic immune activation the transport of the KYN may approach $100 \%$, although if inflammation is limited to the brain, KYN can be produced centrally from TRP [203].

It should also be mentioned that KYNA, as a potent antioxidant metabolite, at higher concentrations can exerts neuroprotection, thus, the clinical significance of KP abnormalities in patients with schizophrenia remains unclear [204]. Thus, the elevation of brain KYNA level, either by administration of L-KYN or pharmacological manipulation of the availability of the KP enzymes, has become an attractive strategy to attenuate neuroinflammatory responses and to protect against glutamate induced excitotoxicity associated with ischemic brain injury $[29,205,206]$. Furthermore, during neuroinflammation both in the periphery and in the brain, KYNA may produce anti-inflammatory responses through the activation of AHRs [30,114,173-175].

In summary, it should be claimed that the role of KP in the etiology of schizophrenia is complex and the literature contains numerous inconsistent findings. Alongside this, physiological variations in patients may occur within different schizophrenic subgroups [196].

\section{The Interplay of Kynurenines and Autonomic Functions}

Some preclinical studies suggest that KP metabolites have significant role in the regulation of the ANS, including cardiovascular, gastrointestinal systems and urinary tract (Table 3) $[159,207,208]$. However, we still do not know exactly, how the KYNA and/or other KP metabolites are involved in the modulation of sympathetic outflow. The results of studies investigating stress-related TRP metabolism supported that, in part through the activation of the hypothalamic-pituitary-adrenal (HPA) axis, including the sympathetic nervous system, the formation of KYNA and other KP metabolites are stimulated [22,209-213]. The increased extracellular concentration of KYNA in rat brain has been associated with reduced cell firing rate in LC, presumably, the endogenous KYNA counterbalances the effects of glutamate (Figure 3) [106,214]. Thus, KYNA is claimed to be a hypotensive agent in rats $[215,216]$. Microinjection of KYNA into the PVN promoted decreased mean arterial blood pressure and heart rate [217] (Figure 3, Table 3). In the ventral part of the medulla and in the NTS many KAT-immunoreactive neurons were found in association with NMDA receptors involved in the control of blood pressure [218]. In agreement with it, glutamate injected into the rostral ventrolateral medulla elevated the blood pressure and heart rate in anesthetized rats, but the centrally administered KYNA lowered the blood pressure (Figure 3, Table 3) [219,220]. 


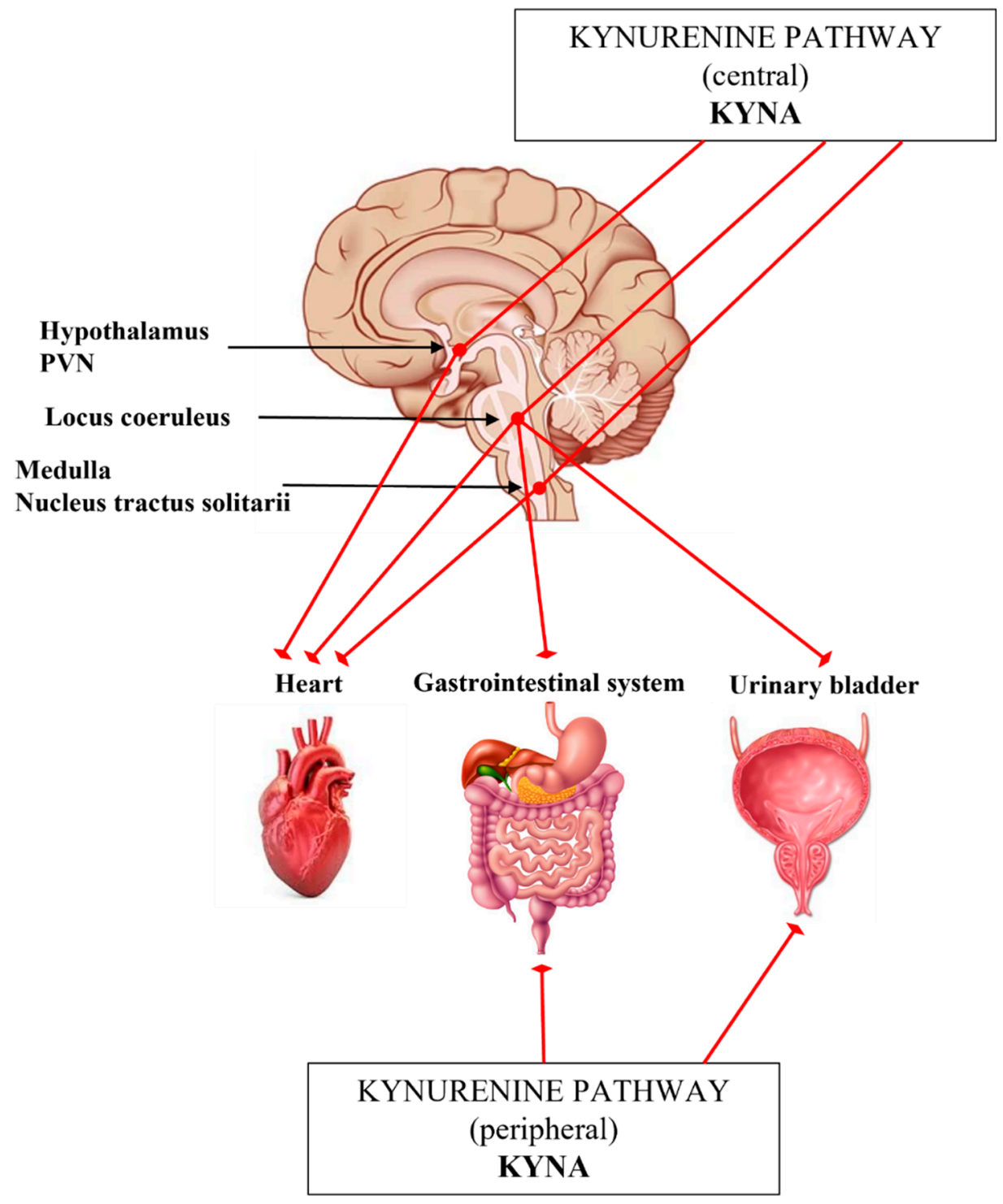

Figure 3. Schematic representation to the Section "The interplay of kynurenines and the autonomic functions". Abbreviations: KYNA: kynurenic acid, PVN: paraventricular nucleus.

In other research, in spontaneous hypertensive rat strain, developed by a missense mutation of KAT-I gene, with abnormally low KYNA levels in the medulla were linked to high blood pressure, which was dose dependently attenuated by L-KYN (Table 3) [221-223]. Furthermore, KYNA microinjection into the NTS in awake rat blocked the processing of the parasympathetic component (bradycardia) of the chemoreflex, however, the pressor response was only partially reduced [224] (Figure 3). Similar results were seen in a working heart-brainstem preparation of rats [230].

Some data suggest that the gastrointestinal function is also influenced by the KP. Thus, the activation of LC neurons by colon distension was significantly antagonized by intracerebroventricular (icv.) administration of KYNA (Table 3) [207]. Gastrointestinal motility regulation is predominantly cholinergic in nature, but NMDARs are also present and abundantly expressed on enteric cholinergic neurons [231-236]. Glutamate or its endogenous receptor agonists/antagonists may participate in modulation of the enteric cholinergic function, since NMDAR activation enhances the nitrogen monoxide dependent acetylcholine release from the myenteric neurons in the ileum and colon (Figure 3) [237-239]. KYNA and SZR72 treatment decreased the motility index, nitric oxide synthase activity and reactive oxygen species in intestinal obstruction and colitis-induced models [33,225-227]. 
Table 3. The interplay of kynurenines and the autonomic functions.

\begin{tabular}{|c|c|c|}
\hline ANS Assessment & Preclinical Findings & References \\
\hline \multirow{2}{*}{ Hypothalamus } & $\begin{array}{l}\text { HPA axis stimulates the formation of KYNA } \\
\text { and other KP metabolites }\end{array}$ & {$[22,209-213,217]$} \\
\hline & $\begin{array}{l}\text { KYNA in the PVN decreased mean arterial } \\
\text { blood pressure and heart rate }\end{array}$ & [217] \\
\hline \multirow[b]{2}{*}{ Brainstem } & L-KYN decreases the elevated blood pressure & [219-223] \\
\hline & $\begin{array}{l}\text { Chemoreflex: KYNA blocked the } \\
\text { parasympathetic component (bradycardia), } \\
\text { pressor response was reduced }\end{array}$ & [224] \\
\hline \multirow[b]{2}{*}{ Gastrointestinal system } & $\begin{array}{c}\text { Activated LC by colon distension antagonized } \\
\text { by administered KYNA }\end{array}$ & [207] \\
\hline & $\begin{array}{c}\text { KYNA decreased the motility index Colitis } \\
\text { model: KYNA and SZR-72 decreased the } \\
\text { motility index, normalized the smooth muscle } \\
\text { tone, had an inhibitory effect on the } \\
\text { colitis-induced high reactive oxygen species } \\
\text { activities }\end{array}$ & {$[33,225-227]$} \\
\hline Urinary system & $\begin{array}{c}\text { KYNA prevented LC elicited by bladder } \\
\text { distention } \\
\text { KYNA inhibited the urinary bladder } \\
\text { contractions evoked by stimulating the pontine } \\
\text { micturition center }\end{array}$ & {$[228,229]$} \\
\hline
\end{tabular}

Abbreviations: HPA: hypothalamic-pituitary-adrenal, KYNA: kynurenic acid, LC: locus coeruleus, L-KYN: Lkynurenine, KP: kynurenine pathway, PVN: paraventricular nucleus.

The KP also has effects on the urinary tract (Figure 3, Table 3). Anatomical and electrophysiological studies have demonstrated the existence of glutamate input from the ventrolateral medulla to the LC. The icv. administered KYNA could prevent both increases in LC discharge rate and EEG activation elicited by bladder distention and inhibited the urinary bladder contractions evoked by stimulating the pontine micturition center $[228,229]$. In a recent study a potential treatment of hyperreflexic urinary bladder and detrusor-sphincter dyssynergia have been investigated in a rat model [208]. The administration of replication-defective herpes simplex virus vectors encoding the KAT2 gene into the bladder wall blocked NMDARs in the lumbosacral dorsal root ganglia, as well as in the lumbosacral micturition center through the enhanced production of KYNA (Figure 3) [208].

\section{The Potential Interaction of the ANS and KP in Schizophrenia, and Molecules Mutually Targeting KP and Autonomic Dysfunctions in Schizophrenia}

It is important to mention that antipsychotic drugs may produce adverse effects on autonomic functioning and sympathovagal balance $[11,14,240,241]$. The extent to which they exacerbate autonomic dysfunction in schizophrenia highly depends on the pharmacodynamics of the antipsychotic taken [14]. These disturbances appear mainly in the cardiovascular system with a negative correlation between neurocardiac control and the degree of antipsychotic affinity and antagonism of muscarinic receptors (M1-M5). Furthermore, antipsychotics with high muscarinic affinity (olanzapine, clozapine and quetiapine) show greater reductions in heart rate variability, than low muscarinic affinity antipsychotics, like risperidone or aripiprazole [242-244]. Additionally, in cases of olanzapine and clozapine, their antiadrenergic properties also play a role in ANS modulation. For example, olanzapine, as an antagonist of $\alpha 1$ adrenergic receptors, causes vasodilation and reduction in blood pressure, which thereby initiates a reflexive sympathetic response. Similarly, clozapine enhances the noradrenergic activity through the antagonism of $\alpha 2$ 
adrenergic receptors [245]. Indeed, studies examining catecholamine levels have revealed that clozapine significantly increases plasma NE [14,246].

Treatment options based on targeting the KYN metabolism in schizophrenia may influence the autonomic signs discussed in this section, although no direct evidence is available for the complex interaction between these systems. Regarding the complex interplay of the ANS, KP and schizophrenia (S4), only few indirect data are available.

As the inflammatory hypothesis of schizophrenia is supported by clinical studies and the $\mathrm{KP}$ is associated with inflammatory processes, thus the schizophrenia-related neuroinflammation could increase KMO-dependent KYN metabolism, leading to the accumulation of 3-HK and QUIN $[34,130,247,248]$. In schizophrenia the blunted type-1 immune response with various inflammatory stimuli in microglia may modify the rate-limiting step of the KP. Thus, TRP is catalyzed by IDO into N-formyl-L-kynurenine in the hypothalamic, pituitary and adrenal areas, influencing the function of ANS $[29,249,250]$. The induction of IDO could potentially result in production of toxic metabolites (3-HK, QUIN), therefore, CNS infections or other inflammatory processes could negatively affect the function of the HPA axis through interferon- $\gamma$ induced upregulation of IDO [250]. Furthermore, decreased serum level of 3-HK following antipsychotic therapy was detected [145].

It is suggested that several ways for the improvements of autonomic signs might be available through influencing the KP in schizophrenia. A review written by Dounay et al. highlights recent advances in medicinal chemistry toward three of the enzyme targets in KP: IDO1, KAT's and KMO [141], and these enzymes have currently the greatest potential as drug targets for preclinical and clinical investigation of the KP. Thus, numerous medicinal chemistry studies are aimed to design novel, potent and selective inhibitors for each of these enzymes [141].

\subsection{Direct Modulators of the KP}

In ketamine-induced schizophrenia rat model the IDO inhibitor 1-methyl-D-tryptophan and the TDO inhibitor allopurinol prevented lipid peroxidation and increased superoxide dismutase and catalase activity in brain region specific manner (Table 4) [130]. Moreover, in a depression mice model glycyrrhizic acid prevented the activated enzymes in KP and the development of depressive-like behaviors [251] Therefore, it was suggested that these $\mathrm{KP}$ inhibitors could represent a viable therapeutic target in treating schizophrenia and other diseases associated with neuroinflammation and oxidative stress. The regulatory region of the tdo2 gene, containing glucocorticoid response elements, could be upregulated by dexamethasone, an anti-inflammatory glucocorticoid drug [130,252-254]. Thus, the expression of TDO is induced by glucocorticoid hormones, glucagon, estrogens, and also regulated by the availability of its substrate, TRP [126,136,255-260]. Moreover, there are reports indicating that TDO activation is stimulated by free radicals. It is suggested that the inhibition of IDO and TDO enzymes promote antioxidant effect via the inhibition of the production KYN metabolites [130]. Co-treatment with antidepressant tianeptine (specifically enhancing serotonin uptake), the allopurinol improved the chronic stress induced depressive-like behavior in rats (Table 4) [261]. However, no potential TDO selective inhibitor has entered clinical trials thus far [261]. 
Table 4. Some therapeutic options may influence the KP.

\begin{tabular}{|c|c|c|c|c|c|c|}
\hline Molecule/Therapy & $\begin{array}{c}\text { Action } \\
\text { Mechanism }\end{array}$ & Effect & Preclinical Model & Ref. & Clinical Study & Ref. \\
\hline $\begin{array}{l}\text { 1-methyl-D- } \\
\text { tryptophan }\end{array}$ & IDO inhibitor & $\begin{array}{c}\text { Decreased } \\
\text { neuroinflammation } \\
\text { and oxidative stress }\end{array}$ & $\begin{array}{c}\text { Ketamine-induced } \\
\text { schizophrenia rat } \\
\text { model }\end{array}$ & [130] & & \\
\hline \multirow[b]{2}{*}{ Allopurinol } & \multirow[b]{2}{*}{ TDO inhibitor } & Antioxidant effect & $\begin{array}{c}\text { Ketamine-induced } \\
\text { schizophrenia rat } \\
\text { model }\end{array}$ & [130] & & \\
\hline & & $\begin{array}{l}\text { Improved } \\
\text { depressive-like } \\
\text { behavior }\end{array}$ & $\begin{array}{c}\text { Chronic } \\
\text { stress-induced } \\
\text { depression mice } \\
\text { model }\end{array}$ & [261] & & \\
\hline D-cycloserine & KAT inhibitor & $\begin{array}{l}\text { Improved cognitive } \\
\text { functions }\end{array}$ & & & Schizophrenia & {$[262,263]$} \\
\hline PF-04859989 & KAT inhibitor & $\begin{array}{l}\text { Restored glutamate } \\
\text { release events }\end{array}$ & $\begin{array}{c}\text { Rat model } \\
\text { exhibiting elevated } \\
\text { KYNA levels }\end{array}$ & [264] & & \\
\hline $\begin{array}{l}\text { Angiotensin } \\
\text { receptor blockers }\end{array}$ & KAT inhibitor & $\begin{array}{l}\text { Reduced KYNA } \\
\text { production }\end{array}$ & Rat cortical slice & {$[215,265-267]$} & & \\
\hline Ro 61-8048 & KMO inhibitor & Neuroprotection & $\begin{array}{l}\text { Gerbil and rat } \\
\text { model of brain } \\
\text { ischemia }\end{array}$ & [268] & & \\
\hline Leucine & $\begin{array}{l}\text { Large neutral } \\
\text { amino acid } \\
\text { transporter } 1 \\
\text { blocker }\end{array}$ & $\begin{array}{l}\text { Prevented systemic } \\
\text { KYN from entering } \\
\text { into the brain }\end{array}$ & $\begin{array}{l}\text { Depression-like } \\
\text { mice model }\end{array}$ & [198] & & \\
\hline \multirow[t]{2}{*}{ VNS } & & $\begin{array}{l}\text { Anti-inflammatory, } \\
\text { Improved heart rate } \\
\text { variability, } \\
\text { low moods and } \\
\text { emotional symptoms }\end{array}$ & & & Depression & {$[269,270]$} \\
\hline & & $\begin{array}{l}\text { Anti-inflammatory } \\
\text { via } \alpha 7 \mathrm{nAChRs}\end{array}$ & & & Schizophrenia & [247] \\
\hline Dipyridamol & $\begin{array}{c}\text { Adenosine } \\
\text { reuptake inhibitor }\end{array}$ & $\begin{array}{l}\text { Greater improvement } \\
\text { in positive symptoms } \\
\text { and general } \\
\text { psychopathology } \\
\text { symptoms }\end{array}$ & & & Schizophrenia & [271] \\
\hline
\end{tabular}

Abbreviation: VNS: vagal nerve stimulation.

Drugs influencing the KAT enzymes are one of the most intensely studied therapeutic approach in schizophrenia [272]. Previous electrophysiological and behavioral studies approaching KAT2 inhibition have confirmed their beneficial effects [114,273-280]. Clinical trials showed that D-cycloserine, has positive effects on cognitive functions in patients with schizophrenia or those experiencing Alzheimer's delusions, by decreasing KYNA levels in the brain by inhibiting KAT1, 2 and 3 [262,263,272]. It has been reported that administration of a systemically available KAT2 inhibitor, PF-04859989, restores glutamate release events in the prefrontal cortex of rats exhibiting elevated KYNA levels [264]. It has been published that angiotensin receptor blockers inhibit KAT2 activity and reduce KYNA production in rat cortical slices (Table 4) [215].

Nowadays, the research is focused on KMO inhibitors to reduce QUIN synthesis thereby reducing neural activity and excitotoxicity in neurodegenerative disorders [281]. Thus, specific KMO inhibitors (e.g., Ro 61-8048) resulted in anticonvulsive, neuroprotective and anti-dyskinetic effects leading to the acceptance of $\mathrm{KMO}$ as a drug target (Table 4) [268,282-286]. On the other hand, an interruption of KMO activity would favor a metabolic shift towards the production of KYNA [194]. Nonetheless, pharmacological inhibition of KMO might also lead to undesirable consequences on the nervous and im- 
mune systems that will have to be evaluated carefully in animals prior to clinical studies, therefore KMO inhibitors are still at the pre-clinical phase of development $[120,276]$.

\subsection{Indirect Modulatory Options of the KP}

As was mentioned above, the BBB integrity is decreased in schizophrenia due to enhanced inflammatory processes, thus a promising treatment strategy might be based on reducing the access of circulating KYN to the brain. In this vein, it has been demonstrated that leucine treatment in mice is a potential method of competitively blocking the large neutral amino acid transporter 1 to prevent systemic KYN from entering into the brain and attenuate the formation of neurotoxic KYN metabolites (Table 4) [198].

Some studies suggested that the parasympathetic activation through vagal nerve stimulation (VNS) inhibited cytokine production, improved heart rate variability, and ameliorated low moods and emotional symptoms in depressive patients resistant to pharmacological treatment $[269,270]$. This method is referred as a promising add-on treatment for treatment-refractory depression, but its application in other psychiatric disorders, such as dementia or schizophrenia is increasingly evaluated (Table 4) [287]. Recent studies have indicated that VNS controls both peripheral and central inflammation via $\alpha 7 n$ AChRs [247]. Since KYNA, as a potent non-competitive $\alpha 7 \mathrm{nAChR}$-antagonist, facilitates disturbances in schizophrenia, the VNS might have a counterbalancing effect [144,247].

Adenosine, an endogenous nucleoside formed by the degradation of adenosinetriphosphate (ATP) during energy-consuming processes, acts as a neuromodulator. It influences multiple physiological processes through activation of four subtypes of G-protein coupled membrane purinergic receptors (A1, A2A, A2B and A3) controlling synaptic plasticity and neurotransmitter release (e.g., glutamate, dopamine and GABA [288-291]. Of relevance to this review adenosine acts on brainstem nuclei involved in autonomic cardiovascular regulation. In general, it decreases sympathetic tone through complex and incompletely understood mechanisms of action [290,291]. The "adenosine hypothesis of schizophrenia" postulates that a reduced adenosinergic tone is involved in the dysregulation of glutamatergic and dopaminergic activity in schizophrenia patients [292-299]. The dopamine level in schizophrenia is, at least partly, under the control of adenosine: reduced activation of presynaptic A1 receptors can trigger increased availability of dopamine leading to increased basal activity of the dopamine D2 receptor, thus promoting psychosis [300-303]. In addition, in the basal ganglia adenosine directly modulates dopaminergic signaling through complexes formed between adenosine and dopamine receptors [304-307]. A2A receptors exert fine regulation of individual synapses and their activation facilitates glutamate release and potentiates NMDAR function [294,308]. Therefore, A2A receptors regulate synaptic plasticity by promoting adequate (or aberrant) adaptive responses in neuronal circuits [294,300,309]. Microinjection of adenosine into the NTS evokes a dose-dependent decrease in blood pressure, heart rate, and renal sympathetic nerve activity, primarily through A2A receptors (Table 4) [310]. That is also the case for the A3 receptor regulating serotonergic and glutamatergic systems [311,312]. A link between adenosine hypofunction and schizophrenia is supported by clinical evidence demonstrating increased enzymatic degradation of adenosine in patients [313,314]. Therefore, this neurotransmitter system might be a potential target for novel drug treatment of several psychiatric conditions, including schizophrenia [315]. An open clinical trial demonstrated that patients treated with a combination of haloperidol and dipyridamol (an adenosine uptake inhibitor, increasing adenosine availability in the synaptic cleft) had a greater improvement in positive symptoms compared with patients treated with haloperidol alone (Table 4) [271,293]. Accordingly, based on informative preclinical studies, adenosine receptor agonists may act as atypical antipsychotic drugs implicating for the proposed use of them in schizophrenia treatment [294,316]. Although neurobiological properties of adenosine may be linked to KYNA, interactions between the adenosinergic system and the KP have not been carefully examined so far. However, both of them are associated with schizophrenia, thus a deeper understanding of their interactions may lead to the development of innovative strategies 
for the treatment of this disorder [292]. Specifically, the effects of combined approaches with adenosine receptor ligands and compounds able to reduce brain KYNA levels (e.g., KAT 2 inhibitors) have not been assessed experimentally so far. These studies might support the development of new multi-target therapeutic strategies that focus on both the purinergic system and KP.

Unfortunately, it should be claimed that none of the above-mentioned treatment options were investigated regarding the autonomic dysfunction of schizophrenia and KP.

\title{
6. Summary and Conclusions
}

There is an established correlation between schizophrenia and autonomic dysregulation, and almost all function of the autonomic nervous system is affected in schizophrenic patients. The investigation of the ANS function in individuals who are at increased risk of developing schizophrenia may be particularly useful to identify the dysregulated physiological patterns at an early stage of schizophrenia, and to develop appropriate interventions [10].

The KYNA hypothesis of schizophrenia is built upon the fact that the elevated KYNA interferes with disturbed glutamatergic and cholinergic transmission [25,123,144-147]. Furthermore, metabolites of the KP can influence the functionality of the autonomic system (see Section 4). Therefore, it might be assumed that an overlap between these systems might have a significant role in the etiology of schizophrenia, however, extensive studies are required to adequately explore this hypothesis. Though the treatment of schizophrenia remains challenging, a better understanding of the interplay between KP and ANS could introduce novel therapeutic options and considerations for drug treatments. Furthermore, it should be mentioned that drugs influencing the KP and/or ANS might be important tools for decreasing antipsychotic-induced adverse effects.

Alterations in KP and ANS are present not only in schizophrenia, but also in other neurological disorders, such as migraine, or neurodegenerative disorders including Huntington's, Alzheimer's, Parkinson's diseases and multiple sclerosis [261,317-323]. Studying the interaction between ANS and KP in different neuropsychiatric disorders might broaden our knowledge to understand mechanisms and disorders apart from schizophrenia and help to find new therapeutic solutions.

Author Contributions: G.H. conceptualized and conveyed the layout of manuscript; A.B., G.K., G.H. and L.V. were involved in writing, drafting, and critically revising the manuscript. All authors have read and agreed to the published version of the manuscript.

Funding: This study is supported by GINOP.2.3.2-15-2016-00034 and TUDFO/47138-1/2019/ITM.

Institutional Review Board Statement: Not applicable.

Informed Consent Statement: Not applicable.

Data Availability Statement: Not applicable.

Conflicts of Interest: The authors declare no conflict of interest.

\author{
Abbreviations \\ $\alpha 7 \mathrm{nAChR} \quad \alpha-7$ nicotinic receptors acetylcholine \\ AHR aryl hydrocarbon receptor \\ AMPAR $\quad \alpha$-amino-3-hydroxy-5-methyl-4-isoxazole propionic acid receptor \\ ANS autonomic nervous system \\ BBB blood-brain barrier \\ CNS central nervous system \\ CSF cerebrospinal fluid \\ GABA $\quad \gamma$-aminobutyric acid \\ GPR35 G-protein-coupled receptor 35 \\ 3-HK 3-hydroxykynurenine
}




$\begin{array}{ll}\text { HPA } & \text { hypothalamic-pituitary-adrenal } \\ \text { IDO } & \text { indoleamine 2,3-dioxygenase } \\ \text { icv } & \text { intracerebroventricular } \\ \text { KAR } & \text { kainite receptor } \\ \text { KAT } & \text { kynurenine aminotransferase } \\ \text { KMO } & \text { kynurenine 3-monooxygenase } \\ \text { KP } & \text { kynurenine pathway } \\ \text { KYNA } & \text { kynurenic acid } \\ \text { KYN } & \text { kynurenine } \\ \text { LC } & \text { locus coeruleus } \\ \text { NE } & \text { norepinephrine } \\ \text { NMDAR } & \text { N-methyl-D-aspartate receptor } \\ \text { NTS } & \text { nucleus tractus solitarii } \\ \text { QUIN } & \text { quinolinic acid } \\ \text { PCP } & \text { phencyclidine } \\ \text { PVN } & \text { paraventricular nucleus } \\ \text { TDO } & \text { tryptophan 2,3-dioxygenase } \\ \text { TRP } & \text { tryptophan } \\ \text { VNS } & \text { vagal nerve stimulation }\end{array}$

\section{References}

1. Stępnicki, P.; Kondej, M.; Kaczor, A.A. Current Concepts and Treatments of Schizophrenia. Molecules 2018, 23, 2087. [CrossRef]

2. Andlin-Sobocki, P.; Jönsson, B.; Wittchen, H.U.; Olesen, J. Cost of disorders of the brain in Europe. Eur. J. Neurol. 2005, 12 (Suppl. 1), 1-27. [CrossRef]

3. Schultz, S.H.; North, S.W.; Shields, C.G. Schizophrenia: A Review. Am. Fam. Physician 2007, 75, 1821-1829. [PubMed]

4. Penadés, R.; Franck, N.; González-Vallespí, L.; Dekerle, M. Neuroimaging Studies of Cognitive Function in Schizophrenia. In Advances in Experimental Medicine and Biology; Springer: New York, NY, USA, 2019; Volume 1118, pp. 117-134.

5. Tandon, R.; Nasrallah, H.A.; Keshavan, M.S. Schizophrenia, "just the facts" 4. Clinical features and conceptualization. Schizophr. Res. 2009, 110, 1-23. [CrossRef] [PubMed]

6. Weinberger, D.R.; Gallhofer, B. Cognitive function in schizophrenia. Int. Clin. Psychopharmacol. 1997, 12, S29. [CrossRef]

7. Bär, K.J.; Koschke, M.; Boettger, M.K.; Berger, S.; Kabisch, A.; Sauer, H.; Voss, A.; Yeragani, V.K. Acute psychosis leads to increased QT variability in patients suffering from schizophrenia. Schizophr. Res. 2007, 95, 115-123. [CrossRef]

8. Bär, K.J.; Boettger, M.K.; Schulz, S.; Harzendorf, C.; Agelink, M.W.; Yeragani, V.K.; Chokka, P.; Voss, A. The interaction between pupil function and cardiovascular regulation in patients with acute schizophrenia. Clin. Neurophysiol. 2008, 119, $2209-2213$. [CrossRef] [PubMed]

9. Bär, K.-J. Cardiac Autonomic Dysfunction in Patients with Schizophrenia and Their Healthy Relatives-A Small Review. Front. Neurol. 2015, 6, 139. [CrossRef]

10. Guccione, C.; Di Scalea, G.L.; Ambrosecchia, M.; Terrone, G.; Di Cesare, G.; Ducci, G.; Schimmenti, A.; Caretti, V. Early signs of schizophrenia and autonomic nervous system dysregulation: A literature review. Clin. Neuropsychiatry 2019, $16,86-97$.

11. Montaquila, J.M.; Trachik, B.J.; Bedwell, J.S. Heart rate variability and vagal tone in schizophrenia: A review. J. Psychiatr. Res. 2015, 69, 57-66. [CrossRef] [PubMed]

12. Rubin, L.S. The Utilization of Pupillometry in the Differential Diagnosis and Treatment of Psychotic and Behavioral Disorders. In Pupillary Dynamics and Behavior; Springer: Boston, MA, USA, 1974; pp. 75-134.

13. Schulz, S.; Bolz, M.; Bär, K.J.; Voss, A. Central-and autonomic nervous system coupling in schizophrenia. Philos. Trans. R. Soc. A Math. Phys. Eng. Sci. 2016, 374, 20150178. [CrossRef]

14. Stogios, N.; Gdanski, A.; Gerretsen, P.; Chintoh, A.F.; Graff-Guerrero, A.; Rajji, T.K.; Remington, G.; Hahn, M.K.; Agarwal, S.M. Autonomic nervous system dysfunction in schizophrenia: Impact on cognitive and metabolic health. npj Schizophr. $2021,7,22$. [CrossRef] [PubMed]

15. Alvares, G.A.; Quintana, D.S.; Hickie, I.B.; Guastella, A.J. Autonomic nervous system dysfunction in psychiatric disorders and the impact of psychotropic medications: A systematic review and meta-analysis. J. Psychiatry Neurosci. 2016, 41, 89-104. [CrossRef]

16. Thayer, J.F.; Yamamoto, S.S.; Brosschot, J.F. The relationship of autonomic imbalance, heart rate variability and cardiovascular disease risk factors. Int. J. Cardiol. 2010, 141, 122-131. [CrossRef]

17. Abi-Dargham, A. Alterations of Serotonin Transmission in Schizophrenia. Int. Rev. Neurobiol. 2007, 78, 133-164. [CrossRef]

18. Kim, J.S.; Kornhuber, H.H.; Schmid-Burgk, W.; Holzmüller, B. Low cerebrospinal fluid glutamate in schizophrenic patients and a new hypothesis on schizophrenia. Neurosci. Lett. 1980, 20, 379-382. [CrossRef]

19. Mäki-Marttunen, V.; Andreassen, O.A.; Espeseth, T. The role of norepinephrine in the pathophysiology of schizophrenia. Neurosci. Biobehav. Rev. 2020, 118, 298-314. [CrossRef]

20. Igbal, N.; van Praag, H.M. The role of serotonin in schizophrenia. Eur. Neuropsychopharmacol. 1995, 5, 11-23. [CrossRef] 
21. Yang, A.; Tsai, S.-J. New targets for schizophrenia treatment beyond the dopamine hypothesis. Int. J. Mol. Sci. 2017, 18, 1689. [CrossRef]

22. Chiappelli, J.; Rowland, L.M.; Notarangelo, F.M.; Wijtenburg, S.A.; Thomas, M.A.R.; Pocivavsek, A.; Jones, A.; Wisner, K.; Kochunov, P.; Schwarcz, R.; et al. Salivary kynurenic acid response to psychological stress: Inverse relationship to cortical glutamate in schizophrenia. Neuropsychopharmacology 2018, 43, 1706-1711. [CrossRef] [PubMed]

23. Nilsson, L.K.; Linderholm, K.R.; Engberg, G.; Paulson, L.; Blennow, K.; Lindström, L.H.; Nordin, C.; Karanti, A.; Persson, P.; Erhardt, S. Elevated levels of kynurenic acid in the cerebrospinal fluid of male patients with schizophrenia. Schizophr. Res. 2005, 80, 315-322. [CrossRef]

24. Koola, M.M. Kynurenine pathway and cognitive impairments in schizophrenia: Pharmacogenetics of galantamine and memantine. Schizophr. Res. Cogn. 2016, 4, 4-9. [CrossRef]

25. Erhardt, S.; Schwieler, L.; Imbeault, S.; Engberg, G. The kynurenine pathway in schizophrenia and bipolar disorder. Neuropharmacology 2017, 112, 297-306. [CrossRef] [PubMed]

26. Ishikawa, M.; Hashimoto, K. $\alpha 7$ nicotinic acetylcholine receptor as a potential therapeutic target for schizophrenia. Curr. Pharm. Des. 2011, 17, 121-129. [CrossRef] [PubMed]

27. Andiné, P.; Lehmann, A.; Ellrén, K.; Wennberg, E.; Kjellmer, I.; Nielsen, T.; Hagberg, H. The excitatory amino acid antagonist kynurenic acid administered after hypoxic-ischemia in neonatal rats offers neuroprotection. Neurosci. Lett. 1988, 90, 208-212. [CrossRef]

28. Foster, A.C.; Vezzani, A.; French, E.D.; Schwarcz, R. Kynurenic acid blocks neurotoxicity and seizures induced in rats by the related brain metabolite quinolinic acid. Neurosci. Lett. 1984, 48, 273-278. [CrossRef]

29. Vécsei, L.; Szalárdy, L.; Fülöp, F.; Toldi, J. Kynurenines in the CNS: Recent advances and new questions. Nat. Rev. Drug Discov. 2013, 12, 64-82. [CrossRef]

30. Fallarini, S.; Magliulo, L.; Paoletti, T.; de Lalla, C.; Lombardi, G. Expression of functional GPR35 in human iNKT cells. Biochem. Biophys. Res. Commun. 2010, 398, 420-425. [CrossRef]

31. Zubcevic, J.; Richards, E.M.; Yang, T.; Kim, S.; Sumners, C.; Pepine, C.J.; Raizada, M.K. Impaired Autonomic Nervous SystemMicrobiome Circuit in Hypertension. Circ. Res. 2019, 125, 104-116. [CrossRef]

32. Muneer, A. Kynurenine Pathway of Tryptophan Metabolism in Neuropsychiatric Disorders: Pathophysiologic and Therapeutic Considerations. Clin. Psychopharmacol. Neurosci. 2020, 18, 507-526. [CrossRef]

33. Kiss, C.; Vécsei, L. Kynurenines in the Brain: Preclinical and Clinical Studies, Therapeutic Considerations. In Handbook of Neurochemistry and Molecular Neurobiology; Springer: New York, NY, USA, 2009; pp. 91-105.

34. Zádori, D.; Veres, G.; Szalárdy, L.; Klivényi, P.; Vécsei, L. Alzheimer's Disease: Recent Concepts on the Relation of Mitochondrial Disturbances, Excitotoxicity, Neuroinflammation, and Kynurenines. J. Alzheimer's Dis. 2018, 62, 523-547. [CrossRef]

35. Kraepelin, E. Psychiatrie: Ein Lehrbuch für Studirende und Aerzte. J. Ment. Sci. 1899, 45, 581-583.

36. Clamor, A.; Lincoln, T.M.; Thayer, J.F.; Koenig, J. Resting vagal activity in schizophrenia: Meta-analysis of heart rate variability as a potential endophenotype. Br. J. Psychiatry 2016, 208, 9-16. [CrossRef]

37. Iwamoto, Y.; Kawanishi, C.; Kishida, I.; Furuno, T.; Fujibayashi, M.; Ishii, C.; Ishii, N.; Moritani, T.; Taguri, M.; Hirayasu, Y. Dose-dependent effect of antipsychotic drugs on autonomic nervous system activity in schizophrenia. BMC Psychiatry 2012, 12, 1-6. [CrossRef]

38. Liu, Y.W.; Tzeng, N.S.; Yeh, C.B.; Kuo, T.B.J.; Huang, S.Y.; Chang, C.C.; Chang, H.A. Reduced cardiac autonomic response to deep breathing: A heritable vulnerability trait in patients with schizophrenia and their healthy first-degree relatives. Psychiatry Res. 2016, 243, 335-341. [CrossRef]

39. Bär, K.J.; Boettger, M.K.; Berger, S.; Baier, V.; Sauer, H.; Yeragani, V.K.; Voss, A. Decreased baroreflex sensitivity in acute schizophrenia. J. Appl. Physiol. 2007, 102, 1051-1056. [CrossRef] [PubMed]

40. Ieda, M.; Miyaoka, T.; Wake, R.; Liaury, K.; Tsuchie, K.; Fukushima, M.; Araki, T.; Ezoe, S.; Inagaki, T.; Horiguchi, J. Evaluation of autonomic nervous system by salivary alpha-amylase level and heart rate variability in patients with schizophrenia. Eur. Arch. Psychiatry Clin. Neurosci. 2014, 264, 83-87. [CrossRef]

41. Birkhofer, A.; Geissendoerfer, J.; Alger, P.; Mueller, A.; Rentrop, M.; Strubel, T.; Leucht, S.; Förstl, H.; Bär, K.J.; Schmidt, G. The deceleration capacity-A new measure of heart rate variability evaluated in patients with schizophrenia and antipsychotic treatment. Eur. Psychiatry 2013, 28, 81-86. [CrossRef] [PubMed]

42. Henry, B.L.; Minassian, A.; Paulus, M.P.; Geyer, M.A.; Perry, W. Heart rate variability in bipolar mania and schizophrenia. J. Psychiatr. Res. 2010, 44, 168-176. [CrossRef] [PubMed]

43. Rechlin, T.; Claus, D.; Weis, M. Heart rate variability in schizophrenic patients and changes of autonomic heart rate parameters during treatment with clozapine. Biol. Psychiatry 1994, 35, 888-892. [CrossRef]

44. Rachow, T.; Berger, S.; Boettger, M.K.; Schulz, S.; Guinjoan, S.; Yeragani, V.K.; Voss, A.; Bär, K.J. Nonlinear relationship between electrodermal activity and heart rate variability in patients with acute schizophrenia. Psychophysiology 2011, 48, 1323-1332. [CrossRef] [PubMed]

45. Lee, J.; Zaki, J.; Harvey, P.O.; Ochsner, K.; Green, M.F. Schizophrenia patients are impaired in empathic accuracy. Psychol. Med. 2011, 41, 2297-2304. [CrossRef] [PubMed]

46. Chang, J.S.; Yoo, C.S.; Yi, S.H.; Hong, K.H.; Oh, H.S.; Hwang, J.Y.; Kim, S.G.; Ahn, Y.M.; Kim, Y.S. Differential pattern of heart rate variability in patients with schizophrenia. Prog. Neuro-Psychopharmacol. Biol. Psychiatry 2009, 33, 991-995. [CrossRef] 
47. Mujica-Parodi, L.R.; Yeragani, V.; Malaspina, D. Nonlinear complexity and spectral analyses of heart rate variability in medicated and unmedicated patients with schizophrenia. Neuropsychobiology 2005, 51, 10-15. [CrossRef]

48. Chong, T.W.H.; Castle, D.J. Layer upon layer: Thermoregulation in schizophrenia. Schizophr. Res. 2004, 69, 149-157. [CrossRef]

49. Pechnick, R.N.; George, R. Characterization of the effects of the acute and chronic administration of phencyclidine on body temperature in the rat: Lack of evidence for the involvement of opiate receptors. J. Pharmacol. Exp. Ther. 1989, 248, 900-906. [PubMed]

50. Radonjić, N.V.; Petronijević, N.D.; Vučković, S.M.; Prostran, M.Š.; Nešić, Z.I.; Todorović, V.R.; Paunović, V.R. Baseline temperature in an animal model of schizophrenia: Long-term effects of perinatal phencyclidine administration. Physiol. Behav. 2008, 93, 437-443. [CrossRef]

51. Madjirova, N.P.; Petrova, N.S.; Delchev, N.K. Daily rhythmicity of temperature, pulse and blood pressure in schizophrenic patients. Schizophr. Res. 1995, 14, 183. [CrossRef]

52. Buck, C.W.; Carscallen, H.B.; Hobbs, G.E. Temperature regulation in schizophrenia: I. comparison of schizophrenic and normal subjects ii. analysis by duration of psychosis. Arch. Neurol. Psychiatry 1950, 64, 828-842. [CrossRef]

53. Bernstein, A.S.; Frith, C.D.; Gruzelier, J.H.; Patterson, T.; Straube, E.; Venables, P.H.; Zahn, T.P. An analysis of the skin conductance orienting response in samples of American, British, and German schizophrenics. Biol. Psychol. 1982, 14, 155-211. [CrossRef]

54. Walker, E.; Shapiro, D.; Esterberg, M.; Trotman, H. Neurodevelopment and schizophrenia: Broadening the focus. Curr. Dir. Psychol. Sci. 2010, 19, 204-208. [CrossRef]

55. Walker, E.F.; Trotman, H.D.; Goulding, S.M.; Holtzman, C.W.; Ryan, A.T.; McDonald, A.; Shapiro, D.I.; Brasfield, J.L. Developmental mechanisms in the prodrome to psychosis. Dev. Psychopathol. 2013, 25, 1585-1600. [CrossRef]

56. Zahn, T.P. Sensitivity of measurement and electrodermal "nonresponding" in schizophrenic and normal subjects. Schizophr. Bull. 1978, 4, 153. [CrossRef]

57. Zahn, T.P.; Carpenter, W.T.; McGlashan, T.H. Autonomic variables related to short-term outcome and clinical improvement in acute schizophrenia. Psychopharmacol. Bull. 1979, 15, 42-43. [PubMed]

58. Zahn, T.P.; Jacobsen, L.K.; Gordon, C.T.; McKenna, K.; Frazier, J.A.; Rapoport, J.L. Autonomic nervous system markers of psychopathology in childhood-onset schizophrenia. Arch. Gen. Psychiatry 1997, 54, 904-912. [CrossRef]

59. Morgan, R.; Cheadle, A.J. Circadian body temperature in chronic schizophrenia. Br. J. Psychiatry 1976, 129, 350-354. [CrossRef] [PubMed]

60. Shiloh, R.; Weizman, A.; Epstein, Y.; Rosenberg, S.L.; Valevski, A.; Dorfman-Etrog, P.; Wiezer, N.; Katz, N.; Munitz, H.; Hermesh, H. Abnormal thermoregulation in drug-free male schizophrenia patients. Eur. Neuropsychopharmacol. 2001, 11, 285-288. [CrossRef]

61. Horvath, G.; Kekesi, G.; Petrovszki, Z.; Benedek, G. Abnormal motor activity and thermoregulation in a schizophrenia rat model for translational science. PLoS ONE 2015, 10, e0143751. [CrossRef] [PubMed]

62. Peupelmann, J.; Quick, C.; Berger, S.; Hocke, M.; Tancer, M.E.; Yeragani, V.K.; Bär, K.J. Linear and non-linear measures indicate gastric dysmotility in patients suffering from acute schizophrenia. Prog. Neuro-Psychopharmacol. Biol. Psychiatry 2009, 33, 1236-1240. [CrossRef] [PubMed]

63. Büki, A.; Kalmár, G.; Kekesi, G.; Benedek, G.; Nyúl, L.G.; Horvath, G. Impaired pupillary control in "schizophrenia-like" WISKET rats. Auton. Neurosci. Basic Clin. 2018, 213, 34-42. [CrossRef]

64. Spohn, H.E.; Patterson, T. Recent studies of psychophysiology in schizophrenia. Schizophr. Bull. 1979, 5, 581-611. [CrossRef]

65. Berger, S.; Hocke, M.; Bär, K.J. Gastric dysmotility in healthy first-degree relatives of patients with schizophrenia. Prog. NeuroPsychopharmacol. Biol. Psychiatry 2010, 34, 1294-1299. [CrossRef]

66. Inagaki, T.; Miyaoka, T.; Okazaki, S.; Yasuda, H.; Kawamukai, T.; Utani, E.; Wake, R.; Hayashida, M.; Horiguchi, J.; Tsuji, S. High salivary alpha-amylase levels in patients with schizophrenia: A pilot study. Prog. Neuro-Psychopharmacol. Biol. Psychiatry 2010, 34, 688-691. [CrossRef]

67. Varsamis, J.; Adamson, J.D. Somatic symptoms in schizophrenia. Can. Psychiatr. Assoc. J. 1976, 21, 1-6. [CrossRef]

68. Kekesi, O.; Tuboly, G.; Szucs, M.; Birkas, E.; Morvay, Z.; Benedek, G.; Horvath, G. Long-lasting, distinct changes in central opioid receptor and urinary bladder functions in models of schizophrenia in rats. Eur. J. Pharmacol. 2011, 661, 35-41. [CrossRef] [PubMed]

69. Brown, S.; Kim, M.; Mitchell, C.; Inskip, H. Twenty-five year mortality of a community cohort with schizophrenia. Br. J. Psychiatry 2010, 196, 116-121. [CrossRef]

70. Chung, M.S.; Yang, A.C.; Lin, Y.C.; Lin, C.N.; Chang, F.R.; Shen, S.H.; Ouyang, W.C.; Loh, E.W.; Chiu, H.J. Association of altered cardiac autonomic function with psychopathology and metabolic profiles in schizophrenia. Psychiatry Res. 2013, 210, 710-715. [CrossRef] [PubMed]

71. Fujibayashi, M.; Matsumoto, T.; Kishida, I.; Kimura, T.; Ishii, C.; Ishii, N.; Moritani, T. Autonomic nervous system activity and psychiatric severity in schizophrenia: Regular article. Psychiatry Clin. Neurosci. 2009, 63, 538-545. [CrossRef]

72. Healy, D.; Le Noury, J.; Harris, M.; Butt, M.; Linden, S.; Whitaker, C.; Zou, L.; Roberts, A.P. Mortality in schizophrenia and related psychoses: Data from two cohorts, 1875-1924 and 1994-2010. BMJ Open 2012, 2, e001810. [CrossRef]

73. Okada, T.; Toichi, M.; Sakihama, M. Influences of an anticholinergic antiparkinsonian drug, parkinsonism, and psychotic symptoms on cardiac autonomic function in schizophrenia. J. Clin. Psychopharmacol. 2003, 23, 441-447. [CrossRef]

74. Olfson, M.; Gerhard, T.; Huang, C.; Crystal, S.; Stroup, T.S. Premature mortality among adults with schizophrenia in the United States. JAMA Psychiatry 2015, 72, 1172-1181. [CrossRef] 
75. Toichi, M.; Kubota, Y.; Murai, T.; Kamio, Y.; Sakihama, M.; Toriuchi, T.; Inakuma, T.; Sengoku, A.; Miyoshi, K. The influence of psychotic states on the autonomic nervous system in schizophrenia. Int. J. Psychophysiol. 1999, 31, 147-154. [CrossRef]

76. Boettger, S.; Hoyer, D.; Falkenhahn, K.; Kaatz, M.; Yeragani, V.K.; Bär, K.J. Altered diurnal autonomic variation and reduced vagal information flow in acute schizophrenia. Clin. Neurophysiol. 2006, 117, 2715-2722. [CrossRef]

77. Kim, J.H.; Ann, J.H.; Lee, J. Relationship between heart rate variability and the severity of psychotic symptoms in schizophrenia. Acta Neuropsychiatr. 2011, 23, 161-166. [CrossRef]

78. Kim, J.H.; Yi, S.H.; Yoo, C.S.; Yang, S.A.; Yoon, S.C.; Lee, K.Y.; Ahn, Y.M.; Kang, U.G.; Kim, Y.S. Heart rate dynamics and their relationship to psychotic symptom severity in clozapine-treated schizophrenic subjects. Prog. Neuro-Psychopharmacol. Biol. Psychiatry 2004, 28, 371-378. [CrossRef]

79. Hattori, S.; Suda, A.; Kishida, I.; Miyauchi, M.; Shiraishi, Y.; Fujibayashi, M.; Tsujita, N.; Ishii, C.; Ishii, N.; Moritani, T.; et al. Association between dysfunction of autonomic nervous system activity and mortality in schizophrenia. Compr. Psychiatry 2018, 86, 119-122. [CrossRef]

80. Hennekens, C.H.; Hennekens, A.R.; Hollar, D.; Casey, D.E. Schizophrenia and increased risks of cardiovascular disease. Am. Heart J. 2005, 150, 1115-1121. [CrossRef]

81. Malpas, S.C. Sympathetic nervous system overactivity and its role in the development of cardiovascular disease. Physiol. Rev. 2010, 90, 513-557. [CrossRef]

82. Aysin, B.; Aysin, E. Effect of respiration in heart rate variability (HRV) analysis. In Proceedings of the Annual International Conference of the IEEE Engineering in Medicine and Biology, New Orleans, LA, USA, 10 April 2006; pp. $1776-1779$.

83. Low, P.A. Evaluation of autonomic function in the autonomic disorders. J. Auton. Nerv. Syst. 1993, 43, 27-29. [CrossRef]

84. Przybylska-Felus, M.; Furgala, A.; Zwolinska-Wcislo, M.; Mazur, M.; Widera, A.; Thor, P.; Mach, T. Disturbances of autonomic nervous system activity and diminished response to stress in patients with celiac disease. J. Physiol. Pharmacol. 2014, 65, 833-841.

85. Tai, Y.C.; Lin, S.-H.; Chen, K.C.; Lee, I.H.; Chen, P.S.; Lee, L.-T.; Tsai, H.C.; Yeh, T.L.; Yang, Y.K. Heart Rate Variability with Deep Breathing in Drug-Naïve Patients with Schizophrenia. Appl. Psychophysiol. Biofeedback 2020, 45, 275-282. [CrossRef]

86. Chatterton, R.T.; Vogelsong, K.M.; Lu, Y.C.; Ellman, A.B.; Hudgens, G.A. Salivary $\alpha$-amylase as a measure of endogenous adrenergic activity. Clin. Physiol. 1996, 16, 433-448. [CrossRef]

87. Nater, U.M.; Rohleder, N. Salivary alpha-amylase as a non-invasive biomarker for the sympathetic nervous system: Current state of research. Psychoneuroendocrinology 2009, 34, 486-496. [CrossRef]

88. Nater, U.M.; La Marca, R.; Florin, L.; Moses, A.; Langhans, W.; Koller, M.M.; Ehlert, U. Stress-induced changes in human salivary alpha-amylase activity-Associations with adrenergic activity. Psychoneuroendocrinology 2006, 31, 49-58. [CrossRef]

89. Kanji, S.; Fonseka, T.M.; Marshe, V.S.; Sriretnakumar, V.; Hahn, M.K.; Müller, D.J. The microbiome-gut-brain axis: Implications for schizophrenia and antipsychotic induced weight gain. Eur. Arch. Psychiatry Clin. Neurosci. 2018, 268, 3-15. [CrossRef]

90. Martin, C.R.; Osadchiy, V.; Kalani, A.; Mayer, E.A. The Brain-Gut-Microbiome Axis. Cell. Mol. Gastroenterol. Hepatol. 2018, 6, 133-148. [CrossRef]

91. Waise, T.M.Z.; Dranse, H.J.; Lam, T.K.T. The metabolic role of vagal afferent innervation. Nat. Rev. Gastroenterol. Hepatol. 2018, 15, 625-636. [CrossRef]

92. Beissner, F.; Meissner, K.; Bär, K.J.; Napadow, V. The autonomic brain: An activation likelihood estimation meta-analysis for central processing of autonomic function. J. Neurosci. 2013, 33, 10503-10511. [CrossRef]

93. Lechan, R.M.; Toni, R. Functional Anatomy of the Hypothalamus and Pituitary. In Endotext; MDText.com, Inc.: South Dartmouth, MA, USA, 2000.

94. Bernstein, H.-G.; Keilhoff, G.; Steiner, J.; Dobrowolny, H.; Bogerts, B. The Hypothalamus in Schizophrenia Research: No Longer a Wallflower Existence. Open Neuroendocrinol. J. 2010, 3, 59-67. [CrossRef]

95. Dougherty, P. Somatosensory Systems (Section 2, Chapter 2) Neuroscience Online: An Electronic Textbook for the Neurosciences I Department of Neurobiology and Anatomy-The University of Texas Medical School at Houston. Available online: https: //nba.uth.tmc.edu/neuroscience/m/s4/chapter03.html (accessed on 21 June 2021).

96. Goldstein, J.M.; Seidman, L.J.; Makris, N.; Ahern, T.; O’Brien, L.M.; Caviness, V.S.; Kennedy, D.N.; Faraone, S.V.; Tsuang, M.T. Hypothalamic Abnormalities in Schizophrenia: Sex Effects and Genetic Vulnerability. Biol. Psychiatry 2007, 61, 935-945. [CrossRef]

97. Klomp, A.; Koolschijn, P.C.M.P.; Hulshoff Pol, H.E.; Kahn, R.S.; Van Haren, N.E.M. Hypothalamus and pituitary volume in schizophrenia: A structural MRI study. Int. J. Neuropsychopharmacol. 2012, 15, 281-288. [CrossRef] [PubMed]

98. Koolschijn, P.C.M.P.; van Haren, N.E.M.; Hulshoff Pol, H.E.; Kahn, R.S. Hypothalamus volume in twin pairs discordant for schizophrenia. Eur. Neuropsychopharmacol. 2008, 18, 312-315. [CrossRef]

99. Tognin, S.; Rambaldelli, G.; Perlini, C.; Bellani, M.; Marinelli, V.; Zoccatelli, G.; Alessandrini, F.; Pizzini, F.B.; Beltramello, A.; Terlevic, R.; et al. Enlarged hypothalamic volumes in schizophrenia. Psychiatry Res.—Neuroimaging 2012, 204, 75-81. [CrossRef]

100. Bernstein, H.G.; Stanarius, A.; Baumann, B.; Henning, H.; Krell, D.; Danos, P.; Falkai, P.; Bogerts, B. Nitric oxide synthasecontaining neurons in the human hypothalamus: Reduced number of immunoreactive cells in the paraventricular nucleus of depressive patients and schizophrenics. Neuroscience 1998, 83, 867-875. [CrossRef]

101. Bernstein, H.G.; Krause, S.; Krell, D.; Dobrowolny, H.; Wolter, M.; Stauch, R.; Ranft, K.; Danos, P.; Jirikowski, G.F.; Bogerts, B. Strongly reduced number of parvalbumin-immunoreactive projection neurons in the mammillary bodies in schizophrenia: Further evidence for limbic neuropathology. Ann. N. Y. Acad. Sci. 2007, 1096, 120-127. [CrossRef]

102. Briess, D.; Cotter, D.; Doshi, R.; Everail, L. Mamillary body abnormalities in schizophrenia. Lancet 1998, 352, 789-790. [CrossRef] 
103. Weinshenker, D.; Holmes, P.V. Regulation of neurological and neuropsychiatric phenotypes by locus coeruleus-derived galanin. Brain Res. 2016, 1641, 320-337. [CrossRef]

104. Szabadi, E. Functional neuroanatomy of the central noradrenergic system. J. Psychopharmacol. 2013, 27, 659-693. [CrossRef]

105. Yamamoto, K.I.; Shinba, T.; Yoshii, M. Psychiatric symptoms of noradrenergic dysfunction: A pathophysiological view. Psychiatry Clin. Neurosci. 2014, 68, 1-20. [CrossRef]

106. Samuels, E.; Szabadi, E. Functional Neuroanatomy of the Noradrenergic Locus Coeruleus: Its Roles in the Regulation of Arousal and Autonomic Function Part I: Principles of Functional Organisation. Curr. Neuropharmacol. 2008, 6, 235-253. [CrossRef]

107. Bondy, B.; Ackenheil, M.; Birzle, W.; Elbers, R.; Fröhler, M. Catecholamines and their receptors in blood: Evidence for alterations in schizophrenia. Biol. Psychiatry 1984, 19, 1377-1393. [PubMed]

108. Kemali, D.; Del Vecchio, M.; Maj, M. Increased noradrenaline levels in CSF and plasma of schizophrenic patients. Biol. Psychiatry 1982, 17, 711-717.

109. Gay, N.; Cottraux, J.A.; Denoroy, L.; Tommasi, M.; Kopp, N. Possible increase of dopamine-beta-hydroxylase activity in the locus ceruleus of paranoid schizophrenic patients: A preliminary post-mortem study. Psychiatry Res. 1989, 27, 31-38. [CrossRef]

110. Wise, C.D.; Stein, L. Dopamine- $\beta$-hydroxylase deficits in the brains of schizophrenic patients. Science (80-) 1973, 181, 344-347. [CrossRef]

111. Benros, M.E.; Eaton, W.W.; Mortensen, P.B. The epidemiologic evidence linking autoimmune diseases and psychosis. Biol. Psychiatry 2014, 75, 300-306. [CrossRef]

112. Khandaker, G.M.; Zimbron, J.; Lewis, G.; Jones, P.B. Prenatal maternal infection, neurodevelopment and adult schizophrenia: A systematic review of population-based studies. Psychol. Med. 2013, 43, 239-257. [CrossRef]

113. Khandaker, G.M.; Zimbron, J.; Dalman, C.; Lewis, G.; Jones, P.B. Childhood infection and adult schizophrenia: A meta-analysis of population-based studies. Schizophr. Res. 2012, 139, 161-168. [CrossRef]

114. Zádor, F.; Nagy-Grócz, G.; Kekesi, G.; Dvorácskó, S.; Szucs, E.; Tömböly, C.; Horvath, G.; Benyhe, S.; Vécsei, L. Kynurenines and the endocannabinoid system in schizophrenia: Common points and potential interactions. Molecules 2019, 24, 3709. [CrossRef] [PubMed]

115. Majewski, M.; Kozlowska, A.; Thoene, M.; Lepiarczyk, E.; Grzegorzewski, W.J. Overview of the role of vitamins and minerals on the kynurenine pathway in health and disease. J. Physiol. Pharmacol. 2016, 67, 3-20.

116. Sas, K.; Szabó, E.; Vécsei, L. Mitochondria, oxidative stress and the kynurenine system, with a focus on ageing and neuroprotection. Molecules 2018, 23, 191. [CrossRef]

117. Pedraz-Petrozzi, B.; Elyamany, O.; Rummel, C.; Mulert, C. Effects of inflammation on the kynurenine pathway in schizophreniaA systematic review. J. Neuroinflamm. 2020, 17, 1-17. [CrossRef]

118. Erhardt, S.; Olsson, S.K.; Engberg, G. Pharmacological manipulation of kynurenic acid: Potential in the treatment of psychiatric disorders. CNS Drugs 2009, 23, 91-101. [CrossRef]

119. Kegel, M.E.; Bhat, M.; Skogh, E.; Samuelsson, M.; Lundberg, K.; Dahl, M.L.; Sellgren, C.; Schwieler, L.; Engberg, G.; SchuppeKoistinen, I.; et al. Imbalanced Kynurenine Pathway in Schizophrenia. Int. J. Tryptophan Res. 2014, 7, 15-22. [CrossRef]

120. Schwarcz, R.; Bruno, J.P.; Muchowski, P.J.; Wu, H.Q. Kynurenines in the mammalian brain: When physiology meets pathology. Nat. Rev. Neurosci. 2012, 13, 465-477. [CrossRef]

121. Tóth, F.; Cseh, E.K.; Vécsei, L. Natural Molecules and Neuroprotection: Kynurenic Acid, Pantethine and $\alpha$-Lipoic Acid. Int. J. Mol. Sci. 2021, 22, 403. [CrossRef]

122. Benedetti, F.; Aggio, V.; Pratesi, M.L.; Greco, G.; Furlan, R. Neuroinflammation in Bipolar Depression. Front. Psychiatry 2020, 11. [CrossRef]

123. Price, J.B.; Bronars, C.; Erhardt, S.; Cullen, K.R.; Schwieler, L.; Berk, M.; Walder, K.; McGee, S.L.; Frye, M.A.; Tye, S.J. Bioenergetics and synaptic plasticity as potential targets for individualizing treatment for depression. Neurosci. Biobehav. Rev. 2018, 90, 212-220. [CrossRef]

124. Stone, T.W. Kynurenines in the CNS: From endogenous obscurity to therapeutic importance. Prog. Neurobiol. 2001, 64, 185-218. [CrossRef]

125. González Esquivel, D.; Ramírez-Ortega, D.; Pineda, B.; Castro, N.; Ríos, C.; Pérez de la Cruz, V. Kynurenine pathway metabolites and enzymes involved in redox reactions. Neuropharmacology 2017, 112, 331-345. [CrossRef]

126. Boros, F.A.; Vécsei, L. Immunomodulatory Effects of Genetic Alterations Affecting the Kynurenine Pathway. Front. Immunol. 2019, 10, 2570. [CrossRef]

127. Lemos, H.; Huang, L.; Prendergast, G.C.; Mellor, A.L. Immune control by amino acid catabolism during tumorigenesis and therapy. Nat. Rev. Cancer 2019, 19, 162-175. [CrossRef]

128. Ye, Z.; Yue, L.; Shi, J.; Shao, M.; Wu, T. Role of IDO and TDO in cancers and related diseases and the therapeutic implications. J. Cancer 2019, 10, 2771-2782. [CrossRef]

129. Golimbet, V.E.; Korovaitseva, G.I.; Gabaeva, M.V.; Velikaya, N.V.; Snegireva, A.A.; Kasparov, S.V.; Kolesina, N.Y.; Ganisheva, T.K.; Savel'eva, T.M. A study of IL-1ß and IDO gene polymorphisms in patients with schizophrenia. Zhurnal Nevrol. Psihiatr. Im. SS Korsakova 2014, 2014, 46-49.

130. Réus, G.Z.; Becker, I.R.T.; Scaini, G.; Petronilho, F.; Oses, J.P.; Kaddurah-Daouk, R.; Ceretta, L.B.; Zugno, A.I.; Dal-Pizzol, F.; Quevedo, J.; et al. The inhibition of the kynurenine pathway prevents behavioral disturbances and oxidative stress in the brain of adult rats subjected to an animal model of schizophrenia. Prog. Neuro-Psychopharmacol. Biol. Psychiatry 2018, 81, 55-63. [CrossRef] 
131. Muller, N.; Schwarz, M.J. The Role of Immune System in Schizophrenia. Curr. Immunol. Rev. 2010, 6, 213-220. [CrossRef]

132. Babcock, T.A.; Carlin, J.M. Transcriptional activation of indoleamine dioxygenase by interleukin 1 and tumor necrosis factor $\alpha$ in interferon-treated epithelial cells. Cytokine 2000, 12, 588-594. [CrossRef]

133. Connor, T.J.; Starr, N.; O'Sullivan, J.B.; Harkin, A. Induction of indolamine 2,3-dioxygenase and kynurenine 3-monooxygenase in rat brain following a systemic inflammatory challenge: A role for IFN- $\gamma$ ? Neurosci. Lett. 2008, 441, 29-34. [CrossRef]

134. O'Connor, J.C.; Andre, C.; Wang, Y.; Lawson, M.A.; Szegedi, S.S.; Lestage, J.; Castanon, N.; Kelley, K.W.; Dantzer, R. Interferonand Tumor Necrosis Factor- Mediate the Upregulation of Indoleamine 2,3-Dioxygenase and the Induction of Depressive-Like Behavior in Mice in Response to Bacillus Calmette-Guerin. J. Neurosci. 2009, 29, 4200-4209. [CrossRef] [PubMed]

135. Zunszain, P.A.; Anacker, C.; Cattaneo, A.; Choudhury, S.; Musaelyan, K.; Myint, A.M.; Thuret, S.; Price, J.; Pariante, C.M. Interleukin-1 $\beta$ : A new regulator of the kynurenine pathway affecting human hippocampal neurogenesis. Neuropsychopharmacology 2012, 37, 939-949. [CrossRef] [PubMed]

136. Batabyal, D.; Yeh, S.R. Human tryptophan dioxygenase: A comparison to indoleamine 2,3-dioxygenase. J. Am. Chem. Soc. 2007, 129, 15690-15701. [CrossRef] [PubMed]

137. Miller, C.L.; Llenos, I.C.; Dulay, J.R.; Barillo, M.M.; Yolken, R.H.; Weis, S. Expression of the kynurenine pathway enzyme tryptophan 2,3-dioxygenase is increased in the frontal cortex of individuals with schizophrenia. Neurobiol. Dis. 2004, 15, 618-629. [CrossRef]

138. Guillemin, G.J.; Cullen, K.M.; Lim, C.K.; Smythe, G.A.; Garner, B.; Kapoor, V.; Takikawa, O.; Brew, B.J. Characterization of the kynurenine pathway in human neurons. J. Neurosci. 2007, 27, 12884-12892. [CrossRef]

139. Han, Q.; Li, J.; Li, J. pH dependence, substrate specificity and inhibition of human kynurenine aminotransferase I. Eur. J. Biochem. 2004, 271, 4804-4814. [CrossRef]

140. Guillemin, G.J.; Kerr, S.J.; Smythe, G.A.; Smith, D.G.; Kapoor, V.; Armati, P.J.; Croitoru, J.; Brew, B.J. Kynurenine pathway metabolism in human astrocytes: A paradox for neuronal protection. J. Neurochem. 2001, 78, 842-853. [CrossRef]

141. Dounay, A.B.; Tuttle, J.B.; Verhoest, P.R. Challenges and Opportunities in the Discovery of New Therapeutics Targeting the Kynurenine Pathway. J. Med. Chem. 2015, 58, 8762-8782. [CrossRef]

142. Guillemin, G.J.; Smythe, G.; Takikawa, O.; Brew, B.J. Expression of Indoleamine 2,3-Dioxygenase and Production of Quinolinic Acid by Human Microglia, Astrocytes, and Neurons. Wiley Online Libr. 2004, 49, 15-23. [CrossRef]

143. Erhardt, S.; Schwieler, L.; Nilsson, L.; Linderholm, K.; Engberg, G. The kynurenic acid hypothesis of schizophrenia. Physiol. Behav. 2007, 92, 203-209. [CrossRef]

144. Hilmas, C.; Pereira, E.F.R.; Alkondon, M.; Rassoulpour, A.; Schwarcz, R.; Albuquerque, E.X. The brain metabolite kynurenic acid inhibits $\alpha 7$ nicotinic receptor activity and increases non- $\alpha 7$ nicotinic receptor expression: Physiopathological implications. J. Neurosci. 2001, 21, 7463-7473. [CrossRef]

145. Myint, A.M.; Schwarz, M.J.; Verkerk, R.; Mueller, H.H.; Zach, J.; Scharpé, S.; Steinbusch, H.W.M.; Leonard, B.E.; Kim, Y.K. Reversal of imbalance between kynurenic acid and 3-hydroxykynurenine by antipsychotics in medication-naïve and medication-free schizophrenic patients. Brain. Behav. Immun. 2011, 25, 1576-1581. [CrossRef]

146. Stone, T.W. Neuropharmacology of quinolinic and kynurenic acids. Pharmacol. Rev. 1993, 45, 309-379.

147. Stone, T.W. Kynurenic acid blocks nicotinic synaptic transmission to hippocampal interneurons in young rats. Eur. J. Neurosci. 2007, 25, 2656-2665. [CrossRef]

148. Zeppillo, T.; Schulmann, A.; Macciardi, F.; Hjelm, B.E.; Föcking, M.; Sequeira, P.A.; Guella, I.; Cotter, D.; Bunney, W.E.; Limon, A.; et al. Functional impairment of cortical AMPA receptors in schizophrenia. Schizophr. Res. 2020. [CrossRef] [PubMed]

149. Beneyto, M.; Kristiansen, L.V.; Oni-Orisan, A.; McCullumsmith, R.E.; Meador-Woodruff, J.H. Abnormal glutamate receptor expression in the medial temporal lobe in schizophrenia and mood disorders. Neuropsychopharmacology 2007, 32, 1888-1902. [CrossRef]

150. Meador-Woodruff, J.H.; Daniel, J.H. Glutamate receptor expression in schizophrenic brain. Brain Res. Rev. 2000, 31, $288-294$. [CrossRef]

151. Alkondon, M.; Pereira, E.F.R.; Eisenberg, H.M.; Kajii, Y.; Schwarcz, R.; Albuquerque, E.X. Age dependency of inhibition of $\alpha 7$ nicotinic receptors and tonically active N-methyl-D-aspartate receptors by endogenously produced kynurenic acid in the brain. $J$. Pharmacol. Exp. Ther. 2011, 337, 572-582. [CrossRef] [PubMed]

152. Lopes, C.; Pereira, E.F.R.; Wu, H.Q.; Purushottamachar, P.; Njar, V.; Schwarcz, R.; Albuquerque, E.X. Competitive antagonism between the nicotinic allosteric potentiating ligand galantamine and kynurenic acid at $\alpha 7^{*}$ nicotinic receptors. J. Pharmacol. Exp. Ther. 2007, 322, 48-58. [CrossRef]

153. Wu, H.-Q.; Pereira, E.F.R.; Bruno, J.P.; Pellicciari, R.; Albuquerque, E.X.; Schwarcz, R. The Astrocyte-Derived $\alpha 7$ Nicotinic Receptor Antagonist Kynurenic Acid Controls Extracellular Glutamate Levels in the Prefrontal Cortex. J. Mol. Neurosci. 2010, 40, 204-210. [CrossRef] [PubMed]

154. Stone, T.W. Does kynurenic acid act on nicotinic receptors? An assessment of the evidence. J. Neurochem. 2020, 152, 627-649. [CrossRef] [PubMed]

155. Stone, T.W. Relationships and Interactions between Ionotropic Glutamate Receptors and Nicotinic Receptors in the CNS. Neuroscience 2021, 468, 321-365. [CrossRef]

156. Schwieler, L.; Erhardt, S. Inhibitory action of clozapine on rat ventral tegmental area dopamine neurons following increased levels of endogenous kynurenic acid. Neuropsychopharmacology 2003, 28, 1770-1777. [CrossRef] 
157. Shepard, P.D.; Joy, B.; Clerkin, L.; Schwarcz, R. Micromolar brain levels of kynurenic acid are associated with a disruption of auditory sensory gating in the rat. Neuropsychopharmacology 2003, 28, 1454-1462. [CrossRef]

158. Schubert, K.O.; Föcking, M.; Cotter, D.R. Proteomic pathway analysis of the hippocampus in schizophrenia and bipolar affective disorder implicates 14-3-3 signaling, aryl hydrocarbon receptor signaling, and glucose metabolism: Potential roles in GABAergic interneuron pathology. Schizophr. Res. 2015, 167, 64-72. [CrossRef] [PubMed]

159. Varga, D.P.; Menyhárt, Á.; Puskás, T.; Bari, F.; Farkas, E.; Kis, Z.; Vécsei, L.; Toldi, J.; Gellért, L. Systemic administration of Lkynurenine sulfate induces cerebral hypoperfusion transients in adult C57Bl/6 mice. Microvasc. Res. 2017, 114, 19-25. [CrossRef] [PubMed]

160. Wang, J.; Simonavicius, N.; Wu, X.; Swaminath, G.; Reagan, J.; Tian, H.; Ling, L. Kynurenic acid as a ligand for orphan G protein-coupled receptor GPR35. J. Biol. Chem. 2006, 281, 22021-22028. [CrossRef] [PubMed]

161. Iaccarino, H.F.; Suckow, R.F.; Xie, S.; Bucci, D.J. The effect of transient increases in kynurenic acid and quinolinic acid levels early in life on behavior in adulthood: Implications for schizophrenia. Schizophr. Res. 2013, 150, 392-397. [CrossRef]

162. Olsson, S.; Larsson, M.; Erhardt, S. Subchronic elevation of brain kynurenic acid augments amphetamine-induced locomotor response in mice. J. Neural Transm. 2012, 119, 155-163. [CrossRef]

163. Pocivavsek, A.; Wu, H.-Q.; Elmer, G.I.; Bruno, J.P.; Schwarcz, R. Pre- and postnatal exposure to kynurenine causes cognitive deficits in adulthood. Eur. J. Neurosci. 2012, 35, 1605-1612. [CrossRef]

164. Trecartin, K.V.; Bucci, D.J. Administration of kynurenine during adolescence, but not during adulthood, impairs social behavior in rats. Schizophr. Res. 2011, 133, 156-158. [CrossRef]

165. Parsons, M.P.; Raymond, L.A. Extrasynaptic NMDA receptor involvement in central nervous system disorders. Neuron 2014, 82, 279-293. [CrossRef]

166. Schwarcz, R. Kynurenines and Glutamate. Multiple Links and Therapeutic Implications. Adv. Pharmacol. 2016, $76,13-37$.

167. Akagbosu, C.O.; Evans, G.C.; Gulick, D.; Suckow, R.F.; Bucci, D.J. Exposure to kynurenic acid during adolescence produces memory deficits in adulthood. Schizophr. Bull. 2012, 38, 769-778. [CrossRef]

168. Alexander, K.S.; Pocivavsek, A.; Wu, H.Q.; Pershing, M.L.; Schwarcz, R.; Bruno, J.P. Early developmental elevations of brain kynurenic acid impair cognitive flexibility in adults: Reversal with galantamine. Neuroscience 2013, 238, 19-28. [CrossRef]

169. Chess, A.C.; Bucci, D.J. Increased concentration of cerebral kynurenic acid alters stimulus processing and conditioned responding. Behav. Brain Res. 2006, 170, 326-332. [CrossRef]

170. Deangeli, N.E.; Todd, T.P.; Chang, S.E.; Yeh, H.H.; Yeh, P.W.; Bucci, D.J. Acid during adolescence increases sign-tracking and impairs long-term potentiation in adulthood. Front. Behav. Neurosci. 2015, 8, 451. [CrossRef] [PubMed]

171. Erhardt, S.; Schwieler, L.; Emanuelsson, C.; Geyer, M. Endogenous kynurenic acid disrupts prepulse inhibition. Biol. Psychiatry 2004, 56, 255-260. [CrossRef]

172. Forrest, C.M.; McNair, K.; Pisar, M.; Khalil, O.S.; Darlington, L.G.; Stone, T.W. Altered hippocampal plasticity by prenatal kynurenine administration, kynurenine-3-monoxygenase (KMO) deletion or galantamine. Neuroscience 2015, 310, 91-105. [CrossRef]

173. Moroni, F.; Cozzi, A.; Sili, M.; Mannaioni, G. Kynurenic acid: A metabolite with multiple actions and multiple targets in brain and periphery. J. Neural Transm. 2012, 119, 133-139. [CrossRef] [PubMed]

174. Nguyen, N.T.; Kimura, A.; Nakahama, T.; Chinen, I.; Masuda, K.; Nohara, K.; Fujii-Kuriyama, Y.; Kishimoto, T. Aryl hydrocarbon receptor negatively regulates dendritic cell immunogenicity via a kynurenine-dependent mechanism. Proc. Natl. Acad. Sci. USA 2010, 107, 19961-19966. [CrossRef] [PubMed]

175. DiNatale, B.C.; Murray, I.A.; Schroeder, J.C.; Flaveny, C.A.; Lahoti, T.S.; Laurenzana, E.M.; Omiecinski, C.J.; Perdew, G.H. Kynurenic acid is a potent endogenous aryl hydrocarbon receptor ligand that synergistically induces interleukin- 6 in the presence of inflammatory signaling. Toxicol. Sci. 2010, 115, 89-97. [CrossRef]

176. Esser, C.; Rannug, A. The aryl hydrocarbon receptor in barrier organ physiology, immunology, and toxicology. Pharmacol. Rev. 2015, 67, 259-279. [CrossRef]

177. Juricek, L.; Coumoul, X. The aryl hydrocarbon receptor and the nervous system. Int. J. Mol. Sci. 2018, 19, 2504. [CrossRef] [PubMed]

178. Linderholm, K.R.; Skogh, E.; Olsson, S.K.; Dahl, M.L.; Holtze, M.; Engberg, G.; Samuelsson, M.; Erhardt, S. Increased levels of kynurenine and kynurenic acid in the CSF of patients with schizophrenia. Schizophr. Bull. 2012, 38, 426-432. [CrossRef]

179. Olsson, S.K.; Samuelsson, M.; Saetre, P.; Lindström, L.; Jönsson, E.G.; Nordin, C.; Engberg, G.; Erhardt, S.; Landén, M. Elevated levels of kynurenic acid in the cerebrospinal fluid of patients with bipolar disorder. J. Psychiatry Neurosci. 2010, 35, 195-199. [CrossRef] [PubMed]

180. Sathyasaikumar, K.V.; Stachowski, E.K.; Wonodi, I.; Roberts, R.C.; Rassoulpour, A.; McMahon, R.P.; Schwarcz, R. Impaired kynurenine pathway metabolism in the prefrontal cortex of individuals with schizophrenia. Schizophr. Bull. 2011, 37, 1147-1156. [CrossRef]

181. Schwarcz, R.; Rassoulpour, A.; Wu, H.Q.; Medoff, D.; Tamminga, C.A.; Roberts, R.C. Increased cortical kynurenate content in schizophrenia. Biol. Psychiatry 2001, 50, 521-530. [CrossRef]

182. Koola, M.M.; Buchanan, R.W.; Pillai, A.; Aitchison, K.J.; Weinberger, D.R.; Aaronson, S.T.; Dickerson, F.B. Potential role of the combination of galantamine and memantine to improve cognition in schizophrenia. Schizophr. Res. 2014, 157, 84-89. [CrossRef] 
183. Bartoli, F.; Cioni, R.M.; Callovini, T.; Cavaleri, D.; Crocamo, C.; Carrà, G. The kynurenine pathway in schizophrenia and other mental disorders: Insight from meta-analyses on the peripheral blood levels of tryptophan and related metabolites. Schizophr. Res. 2021, 232, 61-62. [CrossRef]

184. Morrens, M.; De Picker, L.; Kampen, J.K.; Coppens, V. Blood-based kynurenine pathway alterations in schizophrenia spectrum disorders: A meta-analysis. Schizophr. Res. 2020, 223, 43-52. [CrossRef]

185. Miller, C.L.; Llenos, I.C.; Dulay, J.R.; Weis, S. Upregulation of the initiating step of the kynurenine pathway in postmortem anterior cingulate cortex from individuals with schizophrenia and bipolar disorder. Brain Res. 2006, 1073-1074, 25-37. [CrossRef]

186. Plitman, E.; Iwata, Y.; Caravaggio, F.; Nakajima, S.; Chung, J.K.; Gerretsen, P.; Kim, J.; Takeuchi, H.; Chakravarty, M.M.; Remington, G.; et al. Kynurenic Acid in Schizophrenia: A Systematic Review and Meta-analysis. Schizophr. Bull. 2017, 43, 764-777. [CrossRef]

187. Yao, J.K.; Dougherty, G.G.; Reddy, R.D.; Keshavan, M.S.; Montrose, D.M.; Matson, W.R.; Rozen, S.; Krishnan, R.R.; McEvoy, J.; Kaddurah-Daouk, R. Altered interactions of tryptophan metabolites in first-episode neuroleptic-naive patients with schizophrenia. Mol. Psychiatry 2010, 15, 938-953. [CrossRef]

188. Condray, R.; Dougherty, G.G.; Keshavan, M.S.; Reddy, R.D.; Haas, G.L.; Montrose, D.M.; Matson, W.R.; McEvoy, J.; KaddurahDaouk, R.; Yao, J.K. 3-Hydroxykynurenine and clinical symptoms in first-episode neuroleptic-naive patients with schizophrenia. Int. J. Neuropsychopharmacol. 2011, 14, 756-767. [CrossRef]

189. Oxenkrug, G.; van der Hart, M.; Roeser, J.; Summergrad, P. Anthranilic Acid: A Potential Biomarker and Treatment Target for Schizophrenia. Ann. Psychiatry Ment. Heal. 2016, 4, 1059.

190. Holtze, M.; Saetre, P.; Engberg, G.; Schwieler, L.; Werge, T.; Andreassen, O.A.; Hall, H.; Terenius, L.; Agartz, I.; Jönsson, E.G.; et al. Kynurenine 3-monooxygenase polymorphisms: Relevance for kynurenic acid synthesis in patients with schizophrenia and healthy controls. J. Psychiatry Neurosci. 2012, 37, 53-57. [CrossRef]

191. Lavebratt, C.; Olsson, S.; Backlund, L.; Frisé, L.; Sellgren, C.; Priebe, L.; Nikamo, P.; Träskman-Bendz, L.; Cichon, S.; Vawter, M.P.; et al. The KMO allele encoding Arg 452 is associated with psychotic features in bipolar disorder type 1, and with increased CSF KYNA level and reduced KMO expression. Mol. Psychiatry 2013, 19, 334-341. [CrossRef] [PubMed]

192. Wonodi, I.; Stine, O.C.; Sathyasaikumar, K.V.; Roberts, R.C.; Mitchell, B.D.; Hong, L.E.; Kajii, Y.; Thaker, G.K.; Schwarcz, R. Downregulated kynurenine 3-monooxygenase gene expression and enzyme activity in schizophrenia and genetic association with schizophrenia endophenotypes. Arch. Gen. Psychiatry 2011, 68, 665-674. [CrossRef]

193. Rothermundt, M.; Ponath, G.; Arolt, V. S100B in schizophrenic psychosis. Int. Rev. Neurobiol. 2004, 59, 445-470. [CrossRef] [PubMed]

194. Parrott, J.M.; O'Connor, J.C. Kynurenine 3-Monooxygenase: An Influential Mediator of Neuropathology. Front. Psychiatry 2015, 6, 116. [CrossRef] [PubMed]

195. Miller, A.H. Conceptual Confluence: The Kynurenine Pathway as a Common Target for Ketamine and the Convergence of the Inflammation and Glutamate Hypotheses of Depression. Neuropsychopharmacology 2013, 38, 1607-1608. [CrossRef] [PubMed]

196. O'Farrell, K.; Harkin, A. Stress-related regulation of the kynurenine pathway: Relevance to neuropsychiatric and degenerative disorders. Neuropharmacology 2017, 112, 307-323. [CrossRef]

197. Owe-Young, R.; Webster, N.L.; Mukhtar, M.; Pomerantz, R.J.; Smythe, G.; Walker, D.; Armati, P.J.; Crowe, S.M.; Brew, B.J. Kynurenine pathway metabolism in human blood-brain-barrier cells: Implications for immune tolerance \& neurotoxicity. $J$. Neurochem. 2008, 105, 1346-1357. [CrossRef]

198. Walker, A.K.; Wing, E.E.; Banks, W.A.; Dantzer, R. Leucine competes with kynurenine for blood-to-brain transport and prevents lipopolysaccharide-induced depression-like behavior in mice. Mol. Psychiatry 2019, 24, 1523-1532. [CrossRef]

199. Chopra, K.; Baveja, A.; Kuhad, A. MMPs: A novel drug target for schizophrenia. Expert Opin. Ther. Targets 2015, 19, 77-85. [CrossRef]

200. Monji, A.; Kato, T.A.; Mizoguchi, Y.; Horikawa, H.; Seki, Y.; Kasai, M.; Yamauchi, Y.; Yamada, S.; Kanba, S. Neuroinflammation in schizophrenia especially focused on the role of microglia. Prog. Neuro-Psychopharmacol. Biol. Psychiatry 2013, 42, 115-121. [CrossRef]

201. Monji, A.; Kato, T.; Kanba, S. Cytokines and schizophrenia: Microglia hypothesis of schizophrenia. Psychiatry Clin. Neurosci. 2009, 63, 257-265. [CrossRef]

202. Steiner, J.; Bogerts, B.; Sarnyai, Z.; Walter, M.; Gos, T.; Bernstein, H.-G.; Myint, A.-M. Bridging the gap between the immune and glutamate hypotheses of schizophrenia and major depression: Potential role of glial NMDA receptor modulators and impaired blood-brain barrier integrity. World J. Biol. Psychiatry 2012, 13, 482-492. [CrossRef]

203. Troubat, R.; Barone, P.; Leman, S.; Desmidt, T.; Cressant, A.; Atanasova, B.; Brizard, B.; El Hage, W.; Surget, A.; Belzung, C.; et al. Neuroinflammation and depression: A review. Eur. J. Neurosci. 2021, 53, 151-171. [CrossRef] [PubMed]

204. Chiappelli, J.; Pocivavsek, A.; Nugent, K.L.; Notarangelo, F.M.; Kochunov, P.; Rowland, L.M.; Schwarcz, R.; Hong, L.E. Stressinduced increase in kynurenic acid as a potential biomarker for patients with schizophrenia and distress intolerance. JAMA Psychiatry 2014, 71, 761-768. [CrossRef] [PubMed]

205. Lugo-Huitrón, R.; Blanco-Ayala, T.; Ugalde-Muñiz, P.; Carrillo-Mora, P.; Pedraza-Chaverrí, J.; Silva-Adaya, D.; Maldonado, P.D.; Torres, I.; Pinzón, E.; Ortiz-Islas, E.; et al. On the antioxidant properties of kynurenic acid: Free radical scavenging activity and inhibition of oxidative stress. Neurotoxicol. Teratol. 2011, 33, 538-547. [CrossRef] [PubMed]

206. Tan, L.; Yu, J.-T.; Tan, L. The kynurenine pathway in neurodegenerative diseases: Mechanistic and therapeutic considerations. J. Neurol. Sci. 2012, 323, 1-8. [CrossRef] 
207. Lechner, S.M.; Curtis, A.L.; Brons, R.; Valentino, R.J. Locus coeruleus activation by colon distention: Role of corticotropinreleasing factor and excitatory amino acids. Brain Res. 1997, 756, 114-124. [CrossRef]

208. Wang, Z.; Liao, L. Improvement in detrusor-sphincter dyssynergia by bladder-wall injection of replication-defective herpes simplex virus vector-mediated gene delivery of kynurenine aminotransferase II in spinal cord injury rats. Nat. Publ. Gr. 2017, 55, 155-161. [CrossRef]

209. Manjunath, R.; Ramasarma, T. Stimulation of liver tryptophan pyrrolase during heat exposure. Biochem. J. 1985, 226, 397-402. [CrossRef] [PubMed]

210. Miura, H.; Ozaki, N.; Shirokawa, T.; Isobe, K. Changes in brain tryptophan metabolism elicited by ageing, social environment, and psychological stress in mice. Stress 2008, 11, 160-169. [CrossRef] [PubMed]

211. Nomura, J. Effects of stress and psychotropic drugs on rat liver tryptophan. Endocrinology 1965, 76, 1190-1194. [CrossRef]

212. Pawlak, D.; Takada, Y.; Urano, T.; Takada, A. Serotonergic and kynurenic pathways in rats exposed to foot shock. Brain Res. Bull. 2000, 52, 197-205. [CrossRef]

213. Salter, M.; Pogson, C.I. The role of tryptophan 2,3-dioxygenase in the hormonal control of tryptophan metabolism in isolated rat liver cells: Effects of glucocorticoids and experimental diabetes. Biochem. J. 1985, 229, 499-504. [CrossRef]

214. Savtchenko, L.P.; Korogod, S.M.; Rusakov, D.A. Nicotine-induced excitation of locus coeruleus neurons is blocked by elevated levels of endogenous kynurenic acid. Synapse 2000, 37, 104-108. [CrossRef]

215. Zakrocka, I.; Targowska-Duda, K.M.; Wnorowski, A.; Kocki, T.; Jóźwiak, K.; Turski, W.A. Angiotensin II Type 1 Receptor Blockers Inhibit KAT II Activity in the Brain-Its Possible Clinical Applications. Neurotox. Res. 2017, 32, 639-648. [CrossRef]

216. Mills, E.; Minson, J.; Drolet, G.; Chalmers, J. Effect of intrathecal amino acid receptor antagonists on basal blood pressure and pressor responses to brainstem stimulation in normotensive and hypertensive rats. J. Cardiovasc. Pharmacol. 1990, 15, 877-883. [CrossRef] [PubMed]

217. Mastelari, R.B.; de Abreu, S.B.; de Aguiar Corrêa, F.M.; de Souza, H.C.D.; Martins-Pinge, M.C. Glutamatergic neurotransmission in the hypothalamus PVN on heart rate variability in exercise trained rats. Auton. Neurosci. Basic Clin. 2012, 170, 42-47. [CrossRef]

218. Kapoor, R.; Okuno, E.; Kido, R.; Kapoor, V. Immuno-localization of kynurenine aminotransferase (KAT) in the rat medulla and spinal cord. Neuroreport 1997, 8, 3619-3623. [CrossRef] [PubMed]

219. Ito, S.; Komatsu, K.; Tsukamoto, K.; Sved, A.F. Excitatory amino acids in the rostral ventrolateral medulla support blood pressure in spontaneously hypertensive rats. Hypertension 2000, 35, 413-417. [CrossRef]

220. Willette, R.N.; Punnen-Grandy, S.; Krieger, A.J.; Sapru, H.N. Differential regulation of regional vascular resistance by the rostral and caudal ventrolateral medulla in the rat. J. Auton. Nerv. Syst. 1987, 18, 143-151. [CrossRef]

221. Kapoor, V.; Kapoor, R.; Chalmers, J. Kynurenic acid, an endogenous glutamate antagonist, in SHR and WKY rats: Possible role in central blood pressure regulation. Clin. Exp. Pharmacol. Physiol. 1994, 21, 891-896. [CrossRef]

222. Kwok, J.B.J.; Kapoor, R.; Gotoda, T.; Iwamoto, Y.; Iizuka, Y.; Yamada, N.; Isaacs, K.E.; Kushwaha, V.V.; Bret Church, W.; Schofield, P.R.; et al. A missense mutation in kynurenine aminotransferase-1 in spontaneously hypertensive rats. J. Biol. Chem. 2002, 277, 35779-35782. [CrossRef]

223. Wang, Y.; Liu, H.; McKenzie, G.; Witting, P.K.; Stasch, J.-P.; Hahn, M.; Changsirivathanathamrong, D.; Wu, B.J.; Ball, H.J.; Thomas, S.R.; et al. Kynurenine is an endothelium-derived relaxing factor produced during inflammation. Nat. Med. 2010, 16, 279-285. [CrossRef] [PubMed]

224. Haibara, A.S.; Bonagamba, L.G.H.; Machado, B.H. Sympathoexcitatory neurotransmission of the chemoreflex in the NTS of awake rats. Am. J. Physiol.-Regul. Integr. Comp. Physiol. 1999, 276, R69-R80. [CrossRef]

225. Kaszaki, J.; Palásthy, Z.; Érczes, D.; Rácz, A.; Torday, C.; Varga, G.; Vécsei, L.; Boros, M. Kynurenic acid inhibits intestinal hypermotility and xanthine oxidase activity during experimental colon obstruction in dogs. Neurogastroenterol. Motil. 2008, 20, 53-62. [CrossRef]

226. Knyihar-Csillik, E.; Mihaly, A.; Krisztin-Peva, B.; Robotka, H.; Szatmari, I.; Fulop, F.; Toldi, J.; Csillik, B.; Vécsei, L. The kynurenate analog SZR-72 prevents the nitroglycerol-induced increase of c-fos immunoreactivity in the rat caudal trigeminal nucleus: Comparative studies of the effects of SZR-72 and kynurenic acid. Neurosci. Res. 2008, 61, 429-432. [CrossRef]

227. Varga, G.; Érces, D.; Fazekas, B.; Fülöp, M.; Kovács, T.; Kaszaki, J.; Fülöp, F.; Vécsei, L.; Boros, M. N-Methyl-d-aspartate receptor antagonism decreases motility and inflammatory activation in the early phase of acute experimental colitis in the rat. Neurogastroenterol. Motil. 2010, 22, 217.e68. [CrossRef] [PubMed]

228. Page, M.E.; Akaoka, H.; Aston-Jones, G.; Valentino, R.J. Bladder distention activates noradrenergic locus coeruleus neurons by an excitatory amino acid mechanism. Neuroscience 1992, 51, 555-563. [CrossRef]

229. Iwabuchi, N. Sacral glutamatergic transmission in the descending limb of the micturition reflex in the cat. Fukuoka Igaku Zasshi 1997, 88, 30-38.

230. Braga, V.A.; Machado, B.H. Chemoreflex sympathoexcitation was not altered by the antagonism of glutamate receptors in the commissural nucleus tractus solitarii in the working heart-brainstem preparation of rats. Exp. Physiol. 2006, 91, 551-559. [CrossRef]

231. Furness, J.B.; Kunze, W.A.A.; Bertrand, P.P.; Clerc, N.; Bornstein, J.C. Intrinsic primary afferent neurons of the intestine. Prog. Neurobiol. 1998, 54, 1-18. [CrossRef]

232. Kaszaki, J.; Érces, D.; Varga, G.; Szabó, A.; Vécsei, L.; Boros, M. Kynurenines and intestinal neurotransmission: The role of N-methyl-d-aspartate receptors. J. Neural Transm. 2012, 119, 211-223. [CrossRef] 
233. Liu, M.T.; Rothstein, J.D.; Gershon, M.D.; Kirchgessner, A.L. Glutamatergic enteric neurons. J. Neurosci. 1997, $17,4764-4784$. [CrossRef] [PubMed]

234. Moroni, F.; Luzzi, S.; Franchi-Micheli, S.; Zilletti, L. The presence of N-methyl-d-aspartate-type receptors for glutamic acid in the guinea pig myenteric plexus. Neurosci. Lett. 1986, 68, 57-62. [CrossRef]

235. Shannon, H.E.; Sawyer, B.D. Glutamate receptors of the N-methyl-D-aspartate subtype in the myenteric plexus of the guinea pig ileum. J. Pharmacol. Exp. Ther. 1989, 251, 518-523. [PubMed]

236. Wiley, J.W.; Lu, Y.X.; Owyang, C. Evidence for a glutamatergic neural pathway in the myenteric plexus. Am. J. Physiol. Liver Physiol. 1991, 261, G693-G700. [CrossRef]

237. Giaroni, C.; Zanetti, E.; Chiaravalli, A.M.; Albarello, L.; Dominioni, L.; Capella, C.; Lecchini, S.; Frigo, G. Evidence for a glutamatergic modulation of the cholinergic function in the human enteric nervous system via NMDA receptors. Eur. J. Pharmacol. 2003, 476, 63-69. [CrossRef]

238. Kohjitani, A.; Funahashi, M.; Miyawaki, T.; Hanazaki, M.; Matsuo, R.; Shimada, M. Peripheral N-methyl-D-aspartate receptors modulate nonadrenergic noncholinergic lower esophageal sphincter relaxation in rabbits. Anesth. Analg. 2005, 101, 1681-1688. [CrossRef]

239. Milusheva, E.A.; Kuneva, V.I.; Itzev, D.E.; Kortezova, N.I.; Sperlagh, B.; Mizhorkova, Z.N. Glutamate stimulation of acetylcholine release from myenteric plexus is mediated by endogenous nitric oxide. Brain Res. Bull. 2005, 66, 229-234. [CrossRef]

240. Cohen, H.; Loewenthal, U.; Matar, M.; Kotler, M. Association of autonomic dysfunction and clozapine: Heart rate variability and risk for sudden death in patients with schizophrenia on long-term psychotropic medication. Br. J. Psychiatry 2001, 179, 167-171. [CrossRef]

241. Lamberti, J.S.; Olson, D.; Crilly, J.F.; Olivares, T.; Williams, G.C.; Tu, X.; Tang, W.; Wiener, K.; Dvorin, S.; Dietz, M.B. Prevalence of the metabolic syndrome among patients receiving clozapine. Am. J. Psychiatry 2006, 163, 1273-1276. [CrossRef] [PubMed]

242. Hattori, S.; Kishida, I.; Suda, A.; Miyauchi, M.; Shiraishi, Y.; Fujibayashi, M.; Tsujita, N.; Ishii, C.; Ishii, N.; Moritani, T.; et al. Effects of four atypical antipsychotics on autonomic nervous system activity in schizophrenia. Schizophr. Res. 2018, 193, 134-138. [CrossRef] [PubMed]

243. Huang, W.L.; Chang, L.R.; Kuo, T.B.J.; Lin, Y.H.; Chen, Y.Z.; Yang, C.C.H. Impact of antipsychotics and anticholinergics on autonomic modulation in patients with schizophrenia. J. Clin. Psychopharmacol. 2013, 33, 170-177. [CrossRef] [PubMed]

244. Yuen, J.W.Y.; Kim, D.D.; Procyshyn, R.M.; White, R.F.; Honer, W.G.; Barr, A.M. Clozapine-induced cardiovascular side effects and autonomic dysfunction: A systematic review. Front. Neurosci. 2018, 12, 203. [CrossRef]

245. Kopin, I.J. Catecholamine metabolism: Basic aspects and clinical significance. Pharmacol. Rev. 1985, 37, $333-364$.

246. Brown, A.S.; Gewirtz, G.; Harkavy-Friedman, J.; Cooper, T.; Brébion, G.; Amador, X.F.; Malaspina, D.; Gorman, J.M. Effects of clozapine on plasma catecholamines and relation to treatment response in schizophrenia: A within-subject comparison with haloperidol. Neuropsychopharmacology 1997, 17, 317-325. [CrossRef]

247. Corsi-Zuelli, F.M.d.G.; Brognara, F.; Quirino, G.F.d.S.; Hiroki, C.H.; Fais, R.S.; Del-Ben, C.M.; Ulloa, L.; Salgado, H.C.; Kanashiro, A.; Loureiro, C.M. Neuroimmune Interactions in Schizophrenia: Focus on Vagus Nerve Stimulation and Activation of the Alpha-7 Nicotinic Acetylcholine Receptor. Front. Immunol. 2017, 8, 618. [CrossRef]

248. Réus, G.Z.; Fries, G.R.; Stertz, L.; Badawy, M.; Passos, I.C.; Barichello, T.; Kapczinski, F.; Quevedo, J. The role of inflammation and microglial activation in the pathophysiology of psychiatric disorders. Neuroscience 2015, 300, 141-154. [CrossRef]

249. Konsman, J.P.; Parnet, P.; Dantzer, R. Cytokine-induced sickness behaviour: Mechanisms and implications. Trends Neurosci. 2002, 25, 154-159. [CrossRef]

250. Tu, H.; Rady, P.L.; Juelich, T.; Smith, E.M.; Tyring, S.K.; Hughes, T.K. Cytokine Regulation of Tryptophan Metabolism in the Hypothalamic-Pituitary-Adrenal (HPA) Axis: Implications for Protective and Toxic Consequences in Neuroendocrine Regulation Cell. Mol. Neurobiol. 2005, 25, 673-680. [CrossRef] [PubMed]

251. Wang, B.; Lian, Y.-J.; Dong, X.; Peng, W.; Liu, L.-L.; Su, W.-J.; Gong, H.; Zhang, T.; Jiang, C.-L.; Li, J.-S.; et al. Glycyrrhizic acid ameliorates the kynurenine pathway in association with its antidepressant effect. Behav. Brain Res. 2018, 353, 250-257. [CrossRef] [PubMed]

252. Danesch, U.; Hashimoto, S.; Renkawitz, R.; Schutz, G. Transcriptional regulation of the tryptophan oxygenase gene in rat liver by glucocorticoids. J. Biol. Chem. 1983, 258, 4750-4753. [CrossRef]

253. Danesch, U.; Gloss, B.; Schmid, W.; Schütz, G.; Schüle, R.; Renkawitz, R. Glucocorticoid induction of the rat tryptophan oxygenase gene is mediated by two widely separated glucocorticoid-responsive elements. EMBO J. 1987, 6, 625-630. [CrossRef] [PubMed]

254. Yu, C.P.; Pan, Z.Z.; Luo, D.Y. TDO as a therapeutic target in brain diseases. Metab. Brain Dis. 2016, 31, 737-747. [CrossRef] [PubMed]

255. Nakamura, T.; Shinno, H.; Ichihara, A. Insulin and glucagon as a new regulator system for tryptophan oxygenase activity demonstrated in primary cultured rat hepatocytes. J. Biol. Chem. 1980, 255, 7533-7535. [CrossRef]

256. Braidman, I.P.; Rose, P. Effects of sex hormones on three glucocorticoid-inducible enzymes concerned with amino acid metabolism in rat liver. Endocrinology 1971, 89, 1250-1255. [CrossRef]

257. Schutz, G.; Killewich, L.; Chen, G.; Feigelson, P. Control of the mRNA for hepatic tryptophan oxygenase during hormonal and substrate induction. Proc. Natl. Acad. Sci. USA 1975, 72, 1017-1020. [CrossRef]

258. Wolf, H.; Brown, R.R. Studies on tryptophan metabolism in male subjects treated with hydrocortisone. J. Clin. Endocrinol. Metab. 1971, 33, 838-843. [CrossRef] 
259. Altman, K.; Greengard, O. Correlation of kynurenine excretion with liver tryptophan pyrrolase levels in disease and after hydrocortisone induction. J. Clin. Invest. 1966, 45, 1525-1534. [CrossRef] [PubMed]

260. Knox, W.E.; Mehler, A.H. The adaptive increase of the tryptophan peroxidase-oxidase system of liver. Science (80-) 1951, 113, 237-238. [CrossRef]

261. Qin, Y.; Wang, N.; Zhang, X.; Han, X.; Zhai, X.; Lu, Y. IDO and TDO as a potential therapeutic target in different types of depression. Metab. Brain Dis. 2018, 33, 1787-1800. [CrossRef]

262. Baran, H.; Kepplinger, B. D-cycloserine lowers kynurenic acid formation-New mechanism of action. Eur. Neuropsychopharmacol. 2014, 24, 639-644. [CrossRef]

263. Gottlieb, J.D.; Cather, C.; Shanahan, M.; Creedon, T.; Macklin, E.A.; Goff, D.C. D-cycloserine facilitation of cognitive behavioral therapy for delusions in schizophrenia. Schizophr. Res. 2011, 131, 69-74. [CrossRef]

264. Koshy Cherian, A.; Gritton, H.; Johnson, D.E.; Young, D.; Kozak, R.; Sarter, M. A systemically-available kynurenine aminotransferase II (KAT II) inhibitor restores nicotine-evoked glutamatergic activity in the cortex of rats. Neuropharmacology 2014, 82, 41-48. [CrossRef] [PubMed]

265. Culman, J.; Von Heyer, C.; Piepenburg, B.; Rascher, W.; Unger, T. Effects of systemic treatment with irbesartan and losartan on central responses to angiotensin II in conscious, normotensive rats. Eur. J. Pharmacol. 1999, 367, 255-265. [CrossRef]

266. Kishi, T.; Hirooka, Y.; Sunagawa, K. Sympathoinhibition caused by orally administered telmisartan through inhibition of the AT1 receptor in the rostral ventrolateral medulla of hypertensive rats. Hypertens. Res. 2012, 35, 940-946. [CrossRef]

267. Zhuo, M.; Gebhart, G.F. Effects of neonatal capsaicin treatment on descending modulation of spinal nociception from the rostral, medial medulla in adult rat. Brain Res. 1994, 645, 164-178. [CrossRef]

268. Cozzi, A.; Carpenedo, R.; Moroni, F. Kynurenine hydroxylase inhibitors reduce ischemic brain damage: Studies with (mnitrobenzoyl)-alanine (mNBA) and 3,4-dimethoxy-[-N-4-(nitrophenyl)thiazol-2YL]-benzenesulfonamide (Ro 61-8048) in models of focal or global brain ischemia. J. Cereb. Blood Flow Metab. 1999, 19, 771-777. [CrossRef] [PubMed]

269. Köhler, O.; Benros, M.E.; Nordentoft, M.; Farkouh, M.E.; Iyengar, R.L.; Mors, O.; Krogh, J. Effect of Anti-inflammatory Treatment on Depression, Depressive Symptoms, and Adverse Effects. JAMA Psychiatry 2014, 71, 1381. [CrossRef] [PubMed]

270. Nemeroff, C.B.; Mayberg, H.S.; Krahl, S.E.; McNamara, J.; Frazer, A.; Henry, T.R.; George, M.S.; Charney, D.S.; Brannan, S.K. VNS Therapy in Treatment-Resistant Depression: Clinical Evidence and Putative Neurobiological Mechanisms. Neuropsychopharmacology 2006, 31, 1345-1355. [CrossRef] [PubMed]

271. Akhondzadeh, S.; Shasavand, E.; Jamilian, H.R.; Shabestari, O.; Kamalipour, A. Dipyridamole in the treatment of schizophrenia: Adenosine-dopamine receptor interactions. J. Clin. Pharm. Ther. 2000, 25, 131-137. [CrossRef]

272. Nematollahi, A.; Sun, G.; Jayawickrama, G.S.; Church, W.B. Kynurenine Aminotransferase Isozyme Inhibitors: A Review. Int. J. Mol. Sci. 2016, 17, 946. [CrossRef]

273. Bortz, D.M.; Wu, H.Q.; Schwarcz, R.; Bruno, J.P. Oral administration of a specific kynurenic acid synthesis (KAT II) inhibitor attenuates evoked glutamate release in rat prefrontal cortex. Neuropharmacology 2017, 121, 69-78. [CrossRef]

274. Dounay, A.B.; Anderson, M.; Bechle, B.M.; Campbell, B.M.; Claffey, M.M.; Evdokimov, A.; Evrard, E.; Fonseca, K.R.; Gan, X.; Ghosh, S.; et al. Discovery of Brain-Penetrant, Irreversible Kynurenine Aminotransferase II Inhibitors for Schizophrenia. ACS Med. Chem. Lett. 2012, 3, 187-192. [CrossRef]

275. Dounay, A.B.; Anderson, M.; Bechle, B.M.; Evrard, E.; Gan, X.; Kim, J.Y.; McAllister, L.A.; Pandit, J.; Rong, S.; Salafia, M.A.; et al. PF-04859989 as a template for structure-based drug design: Identification of new pyrazole series of irreversible KAT II inhibitors with improved lipophilic efficiency. Bioorganic Med. Chem. Lett. 2013, 23, 1961-1966. [CrossRef] [PubMed]

276. Jacobs, K.R.; Castellano-González, G.; Guillemin, G.J.; Lovejoy, D.B. Major Developments in the Design of Inhibitors along the Kynurenine Pathway. Curr. Med. Chem. 2017, 24, 2471. [CrossRef]

277. Jayawickrama, G.S.; Nematollahi, A.; Sun, G.; Church, W.B. Improvement of kynurenine aminotransferase-II inhibitors guided by mimicking sulfate esters. PLoS ONE 2018, 13, e0196404. [CrossRef] [PubMed]

278. Jayawickrama, G.S.; Nematollahi, A.; Sun, G.; Gorrell, M.D.; Church, W.B. Inhibition of human kynurenine aminotransferase isozymes by estrogen and its derivatives. Sci. Rep. 2017, 7, 17559. [CrossRef] [PubMed]

279. Pocivavsek, A.; Elmer, G.I.; Schwarcz, R. Inhibition of kynurenine aminotransferase II attenuates hippocampus-dependent memory deficit in adult rats treated prenatally with kynurenine. Hippocampus 2019, 29, 73-77. [CrossRef] [PubMed]

280. Wu, H.Q.; Okuyama, M.; Kajii, Y.; Pocivavsek, A.; Bruno, J.P.; Schwarcz, R. Targeting kynurenine aminotransferase II in psychiatric diseases: Promising effects of an orally active enzyme inhibitor. Schizophr. Bull. 2014, 40, 152-158. [CrossRef]

281. Huang, Y.-S.; Ogbechi, J.; Clanchy, F.I.; Williams, R.O.; Stone, T.W. IDO and Kynurenine Metabolites in Peripheral and CNS Disorders. Front. Immunol. 2020, 11, 388. [CrossRef]

282. Giorgini, F.; Huang, S.Y.; Sathyasaikumar, K.V.; Notarangelo, F.M.; Thomas, M.A.R.; Tararina, M.; Wu, H.Q.; Schwarcz, R.; Muchowski, P.J. Targeted deletion of kynurenine 3-monooxygenase in mice: A new tool for studying kynurenine pathway metabolism in periphery and brain. J. Biol. Chem. 2013, 288, 36554-36566. [CrossRef] [PubMed]

283. Amaral, M.; Levy, C.; Heyes, D.J.; Lafite, P.; Outeiro, T.F.; Giorgini, F.; Leys, D.; Scrutton, N.S. Structural basis of kynurenine 3-monooxygenase inhibition. Nature 2013, 496, 382-385. [CrossRef]

284. Chiarugi, A.; Carpenedo, R.; Molina, M.T.; Mattoli, L.; Pellicciari, R.; Moroni, F. Comparison of the Neurochemical and Behavioral Effects Resulting from the Inhibition of Kynurenine Hydroxylase and/or Kynureninase. J. Neurochem. 1995, 65, 1176-1183. [CrossRef] [PubMed] 
285. Grégoire, L.; Rassoulpour, A.; Guidetti, P.; Samadi, P.; Bédard, P.J.; Izzo, E.; Schwarcz, R.; Di Paolo, T. Prolonged kynurenine 3-hydroxylase inhibition reduces development of levodopa-induced dyskinesias in parkinsonian monkeys. Behav. Brain Res. 2008, 186, 161-167. [CrossRef] [PubMed]

286. Zwilling, D.; Huang, S.Y.; Sathyasaikumar, K.V.; Notarangelo, F.M.; Guidetti, P.; Wu, H.Q.; Lee, J.; Truong, J.; Andrews-Zwilling, Y.; Hsieh, E.W.; et al. Kynurenine 3-monooxygenase inhibition in blood ameliorates neurodegeneration. Cell 2011, 145, 863-874. [CrossRef]

287. Cimpianu, C.-L.; Strube, W.; Falkai, P.; Palm, U.; Hasan, A. Vagus nerve stimulation in psychiatry: A systematic review of the available evidence. J. Neural Transm. 2017, 124, 145-158. [CrossRef]

288. Cunha, R.A. Neuroprotection by adenosine in the brain: From A1 receptor activation to A2A receptor blockade. Purinergic Signal. 2005, 1, 111-134. [CrossRef]

289. Fredholm, B.B.; Chen, J.F.; Cunha, R.A.; Svenningsson, P.; Vaugeois, J.M. Adenosine and Brain Function. Int. Rev. Neurobiol. 2005, 63, 191-270. [CrossRef] [PubMed]

290. Biaggioni, I. Adenosine Receptors and Autonomic Regulation. In Primer on the Autonomic Nervous System; Elsevier: Amsterdam, The Netherlands, 2012; pp. 95-97. ISBN 9780123865250.

291. Biaggioni, I. The pharmacology of autonomic failure: From hypotension to hypertension. Pharmacol. Rev. 2017, 69, 53-62. [CrossRef] [PubMed]

292. Beggiato, S.; Zuccarini, M.; Cassano, T.; Borroto-Escuela, D.O.; Di Iorio, P.; Schwarcz, R.; Fuxe, K.; Ferraro, L. Adenosine and Kynurenic Acid Interactions: Possible Relevance for Schizophrenia Treatment? Front. Pharmacol. 2021, 12, 589. [CrossRef] [PubMed]

293. Cheffer, A.; Castillo, A.R.G.; Corrêa-Velloso, J.; Gonçalves, M.C.B.; Naaldijk, Y.; Nascimento, I.C.; Burnstock, G.; Ulrich, H. Purinergic system in psychiatric diseases. Mol. Psychiatry 2018, 23, 94-106. [CrossRef]

294. Krügel, U. Purinergic receptors in psychiatric disorders. Neuropharmacology 2016, 104, 212-225. [CrossRef]

295. Lara, D.R.; Souza, D.O. Schizophrenia: A purinergic hypothesis. Med. Hypotheses 2000, 54, 157-166. [CrossRef]

296. Boison, D.; Singer, P.; Shen, H.Y.; Feldon, J.; Yee, B.K. Adenosine hypothesis of schizophrenia-Opportunities for pharmacotherapy. Neuropharmacology 2012, 62, 1527-1543. [CrossRef] [PubMed]

297. Hirota, T.; Kishi, T. Adenosine hypothesis in schizophrenia and bipolar disorder: A systematic review and meta-analysis of randomized controlled trial of adjuvant purinergic modulators. Schizophr. Res. 2013, 149, 88-95. [CrossRef]

298. Lara, D.R.; Dall'Igna, O.P.; Ghisolfi, E.S.; Brunstein, M.G. Involvement of adenosine in the neurobiology of schizophrenia and its therapeutic implications. Prog. Neuro-Psychopharmacol. Biol. Psychiatry 2006, 30, 617-629. [CrossRef]

299. Rial, D.; Lara, D.R.; Cunha, R.A. The Adenosine Neuromodulation System in Schizophrenia. In International Review of Neurobiology; Academic Press Inc.: Cambridge, MA, USA, 2014; Volume 119, pp. 395-449.

300. Boison, D.; Aronica, E. Comorbidities in Neurology: Is adenosine the common link? Neuropharmacology 2015, 97, 18-34. [CrossRef]

301. Borycz, J.; Pereira, M.F.; Melani, A.; Rodrigues, R.J.; Köfalvi, A.; Panlilio, L.; Pedata, F.; Goldberg, S.R.; Cunha, R.A.; Ferré, S. Differential glutamate-dependent and glutamate-independent adenosine A 1 receptor-mediated modulation of dopamine release in different striatal compartments. J. Neurochem. 2007, 101, 355-363. [CrossRef]

302. Seeman, P.; Kapur, S. Schizophrenia: More dopamine, more D2 receptors. Proc. Natl. Acad. Sci. USA 2000, 97, 7673-7675. [CrossRef] [PubMed]

303. Tost, H.; Alam, T.; Meyer-Lindenberg, A. Dopamine and psychosis: Theory, pathomechanisms and intermediate phenotypes. Neurosci. Biobehav. Rev. 2010, 34, 689-700. [CrossRef] [PubMed]

304. Fuxe, K.; Agnati, L.F.; Jacobsen, K.; Hillion, J.; Canals, M.; Torvinen, M.; Tinner-Staines, B.; Staines, W.; Rosin, D.; Terasmaa, A.; et al. Receptor heteromerization in adenosine A2A receptor signaling: Relevance for striatal function and Parkinson's disease. Neurology 2003, 61, S19-S23. [CrossRef] [PubMed]

305. Fuxe, K.; Marcellino, D.; Leo, G.; Agnati, L.F. Molecular integration via allosteric interactions in receptor heteromers. A working hypothesis. Curr. Opin. Pharmacol. 2010, 10, 14-22. [CrossRef] [PubMed]

306. Fuxe, K.; Ferré, S.; Genedani, S.; Franco, R.; Agnati, L.F. Adenosine receptor-dopamine receptor interactions in the basal ganglia and their relevance for brain function. Physiol. Behav. 2007, 92, 210-217. [CrossRef]

307. Fuxe, K.; Marcellino, D.; Genedani, S.; Agnati, L. Adenosine A 2A receptors, dopamine D 2 receptors and their interactions in Parkinson's disease. Mov. Disord. 2007, 22, 1990-2017. [CrossRef] [PubMed]

308. Hines, D.J.; Haydon, P.G. Astrocytic adenosine: From synapses to psychiatric disorders. Philos. Trans. R. Soc. B Biol. Sci. 2014, 369, 20130594. [CrossRef] [PubMed]

309. Azdad, K.; Gall, D.; Woods, A.S.; Ledent, C.; Ferré, S.; Schiffmann, S.N. Dopamine D2 and adenosine A2A receptors regulate NMDA-mediated excitation in accumbens neurons through A2A-D 2 receptor heteromerization. Neuropsychopharmacology 2009, 34, 972-986. [CrossRef]

310. Phillis, J.W.; Scislo, T.J.; O'Leary, D.S. Purines and the nucleus tractus solitarius: Effects on cardiovascular and respiratory function. Clin. Exp. Pharmacol. Physiol. 1997, 24, 738-742. [CrossRef]

311. Campbell, N.G.; Zhu, C.-B.; Lindler, K.M.; Yaspan, B.L.; Kistner-Griffin, E.; Hewlett, W.A.; Tate, C.G.; Blakely, R.D.; Sutcliffe, J.S. Rare coding variants of the adenosine A3 receptor are increased in autism: On the trail of the serotonin transporter regulome. Mol. Autism 2013, 4, 28. [CrossRef] [PubMed] 
312. Dennis, S.H.; Jaafari, N.; Cimarosti, H.; Hanley, J.G.; Henley, J.M.; Mellor, J.R. Oxygen/glucose deprivation induces a reduction in synaptic AMPA receptors on hippocampal CA3 neurons mediated by mGluR1 and adenosine A3 receptors. J. Neurosci. 2011, 31, 11941-11952. [CrossRef] [PubMed]

313. Brunstein, M.G.; Silveira, E.M.; Chaves, L.S.; Machado, H.; Schenkel, O.; Belmonte-de-Abreu, P.; Souza, D.O.; Lara, D.R Increased serum adenosine deaminase activity in schizophrenic receiving antipsychotic treatment. Neurosci. Lett. 2007, 414, 61-64. [CrossRef]

314. Dutra, G.P.; Ottoni, G.L.; Lara, D.R.; Bogo, M.R. Lower frequency of the low activity adenosine deaminase allelic variant (ADA1*2) in schizophrenic patients. Rev. Bras. Psiquiatr. 2010, 32, 275-278. [CrossRef]

315. Cunha, R.; Ferre, S.; Vaugeois, J.-M.; Chen, J.-F. Potential Therapeutic Interest of Adenosine A2A Receptors in Psychiatric Disorders. Curr. Pharm. Des. 2008, 14, 1512-1524. [CrossRef] [PubMed]

316. Borroto-Escuela, D.O.; Fuxe, K. Adenosine heteroreceptor complexes in the basal ganglia are implicated in Parkinson's disease and its treatment. J. Neural Transm. 2019, 126, 455-471. [CrossRef] [PubMed]

317. Andrich, J.; Schmitz, T.; Saft, C.; Postert, T.; Kraus, P.; Epplen, J.T.; Przuntek, H.; Agelink, M.W. Autonomic nervous system function in Huntington's disease. J. Neurol. Neurosurg. Psychiatry 2002, 72, 726-731. [CrossRef]

318. Eren, O.E.; Ruscheweyh, R.; Schankin, C.; Schöberl, F.; Straube, A. The cold pressor test in interictal migraine patients-Different parasympathetic pupillary response indicates dysbalance of the cranial autonomic nervous system. BMC Neurol. 2018, 18, 1-9. [CrossRef] [PubMed]

319. Nagy-Grócz, G.; Laborc, K.F.; Veres, G.; Bajtai, A.; Bohár, Z.; Zádori, D.; Fejes-Szabó, A.; Spekker, E.; Vécsei, L.; Párdutz, Á. The Effect of Systemic Nitroglycerin Administration on the Kynurenine Pathway in the Rat. Front. Neurol. 2017, 8, 278. [CrossRef]

320. Pintér, A.; Cseh, D.; Sárközi, A.; Illigens, B.; Siepmann, T. Autonomic Dysregulation in Multiple Sclerosis. Int. J. Mol. Sci. 2015, 16, 16920-16952. [CrossRef]

321. Venkatesan, D.; Iyer, M.; Narayanasamy, A.; Siva, K.; Vellingiri, B. Kynurenine pathway in Parkinson's disease-An update. eNeurologicalSci 2020, 21, 100270. [CrossRef] [PubMed]

322. Won, E.; Kim, Y.-K. Stress, the Autonomic Nervous System, and the Immune-kynurenine Pathway in the Etiology of Depression. Curr. Neuropharmacol. 2016, 14, 665-673. [CrossRef] [PubMed]

323. Bryn, V.; Verkerk, R.; Skjeldal, O.H.; Saugstad, O.D.; Ormstad, H. Kynurenine Pathway in Autism Spectrum Disorders in Children. Neuropsychobiology 2017, 76, 82-88. [CrossRef] [PubMed] 